The Free Internet Journal

for Organic Chemistry
Review

Arkivoc 2017, part ii, 457-491

\title{
Biological and chemical interest in selenium: a brief historical account
}

\author{
João B. T. Rocha, ${ }^{a, b, *}$ Bruna C. Piccoli, ${ }^{b}$ and Cláudia S. Oliveira ${ }^{b}$ \\ ${ }^{a}$ Departamento de Bioquímica e Biologia Molecular, Centro de Ciências Naturais e Exatas, \\ Universidade Federal de Santa Maria,Santa Maria, RS, Brazil \\ ${ }^{b}$ Programa de Pós-graduação em Ciências Biológicas: Bioquímica Toxicológica, \\ Centro de Ciências Naturais e Exatas, Universidade Federal de Santa Maria,Santa Maria, RS, Brazil \\ E-mail: jbtrocha@yahoo.com.br
}

Dedicated to Prof. Dr. Jacek Młochowski on the occasion of his $80^{\text {th }}$ anniversary

Received 07-06-2016

Accepted 09-24-2016

Published on line 12-27-2016

\section{Abstract}

This review presents a brief account of the discovery, importance, and use of selenium. Based in the importance of selenoproteins, their mechanism of reaction with the participation of selenium, as a selenol $(-\mathrm{SeH})$ group, are indicated. Since the selenol group is the softest nucleophile center found in life, a brief discussion about the synthesis and possible antioxidant and selenoprotein mimetic effects of the organoselenium compounds that can generate the selenol group is presented.

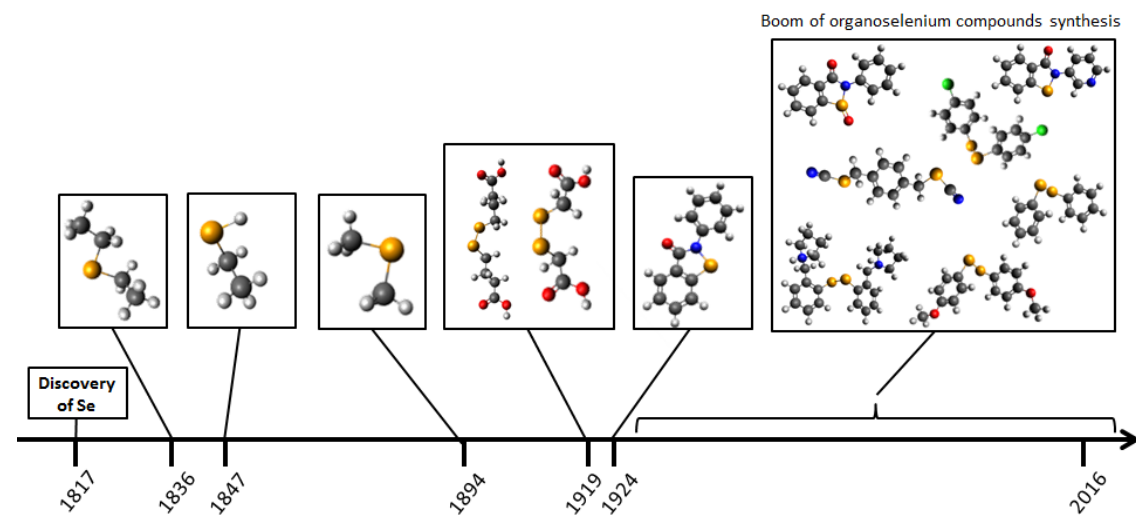

Keywords: Selenol, organoselenium compounds, selenoprotein mimetic, selenite toxicity 


\section{Table of Contents}

1. Introduction

1.1 The selenol group: the softest of the nucleophiles in cell biology

1.2 The essentiality of selenium to life

2. Chemical Interest in the Use of Selenium in Organic Synthesis

2.1 A brief history of the synthesis of organoselenium compounds

2.2 Re-discovery of Ebselen: can the chemist imitate chemistry of life?

3. Biological Interest in Selenium: a Brief Historical Account

\subsection{Early history of inorganic selenium toxicology}

3.2 Oxidation of thiol groups and toxicity of inorganic selenium forms

3.3 Therapeutic use of inorganic selenium

3.4 Toxicology of naturally occurring organoselenium compounds: selenium as a causative factor of livestock poisoning

4. The Biological and Pharmacological Interest in Synthetic Organoselenium Compounds: an Overview 4.1 The early pharmacological and nutritional use of synthetic organoselenium compounds

5. Concluding Remarks and Perspectives

References

\section{Introduction}

\subsection{The selenol group: the softest of the nucleophiles in cell biology}

Since the discovery of selenium by Berzelius in 1817, the chemical and the biological interest in this element has been growing along the years. ${ }^{1-3}$ Nowadays, we have a good understanding about its chemistry but only a partial knowledge about its role in the living cell - physiology or toxicology. The most common inorganic and organic forms of selenium found in the environment and in living cells are depicted in Tables 1 and 2.

Table 1. Inorganic and simple organic forms of selenium found in the environment and/or in living cells

\begin{tabular}{|c|c|c|c|}
\hline Name & $\begin{array}{l}\text { Molecular } \\
\text { structure }\end{array}$ & $\begin{array}{l}\text { Molecular } \\
\text { formulae }\end{array}$ & Distribution \\
\hline Selenium, elemental & [COMPLEX STRUCTURE] & $\mathrm{Se}^{0}$ & Soil \\
\hline $\begin{array}{c}\text { Hydrogen selenide } \\
\text { Selenide }\end{array}$ & $\mathrm{H}_{\mathrm{Se}^{-}}{ }^{-\mathrm{H}}$ & $\mathrm{H}_{2} \mathrm{Se} ; \mathrm{Se}^{2-}$ & Mammals \\
\hline Selenate & $\mathrm{O}=\underset{\substack{\mathrm{Se}^{-} \\
\mathrm{O}}}{\mathrm{O}}-\mathrm{O}^{-}$ & $\mathrm{SeO}_{2}{ }^{-}$ & $\begin{array}{l}\text { Soil, plants and } \\
\text { mammals }\end{array}$ \\
\hline Selenite & $\mathrm{O}_{\mathrm{O}^{\prime}}^{-} \mathrm{Se}-\mathrm{O}^{-}$ & $\mathrm{SeO}_{3}{ }^{2-}$ & $\begin{array}{l}\text { Soil, plants and } \\
\text { mammals }\end{array}$ \\
\hline
\end{tabular}


Table 1. Continued

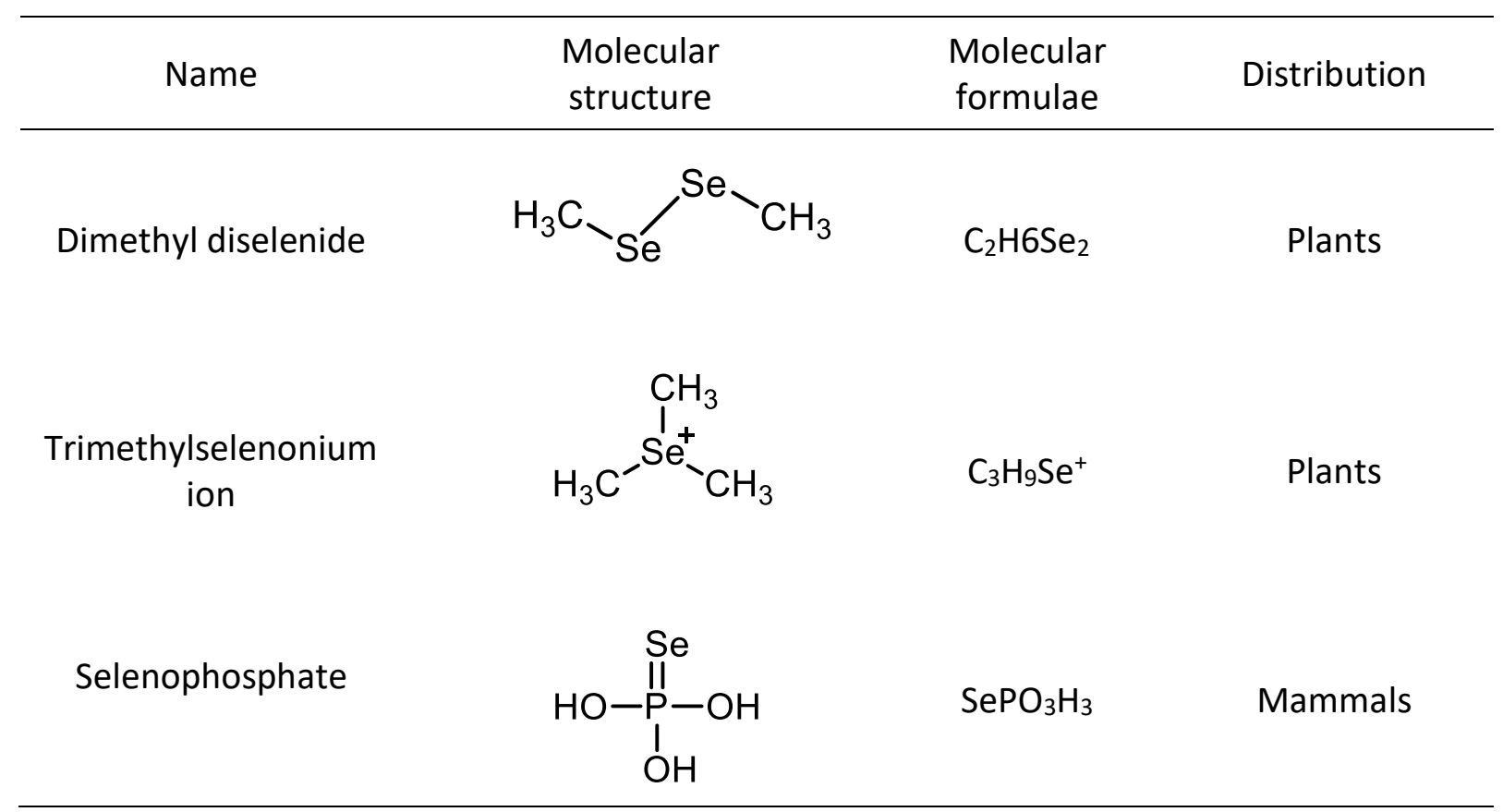

Table 2. Amino acids-, amino acid derivatives-, peptides-, and protein-containing selenium found in plants and/or mammals

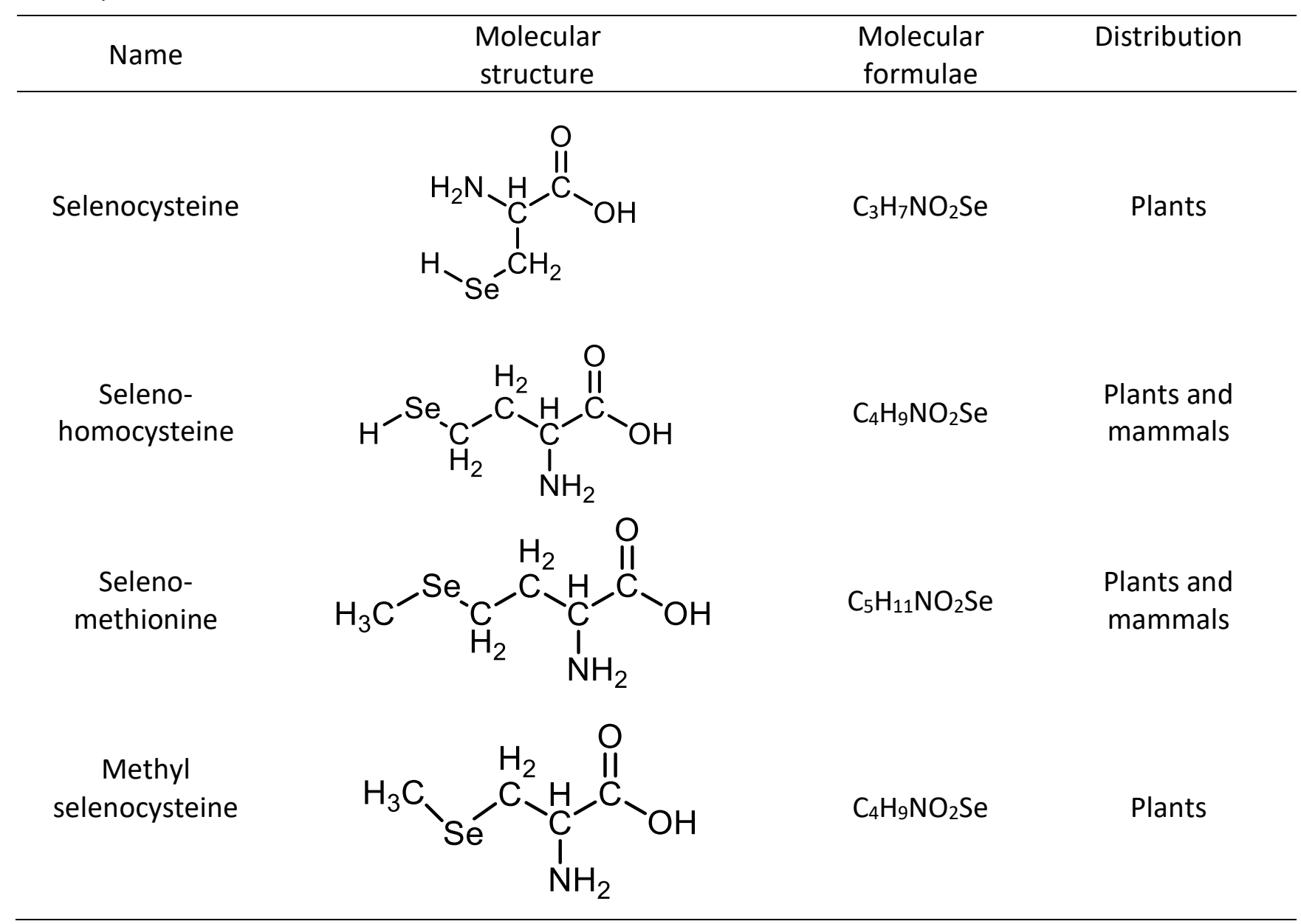


Table 2. Continued

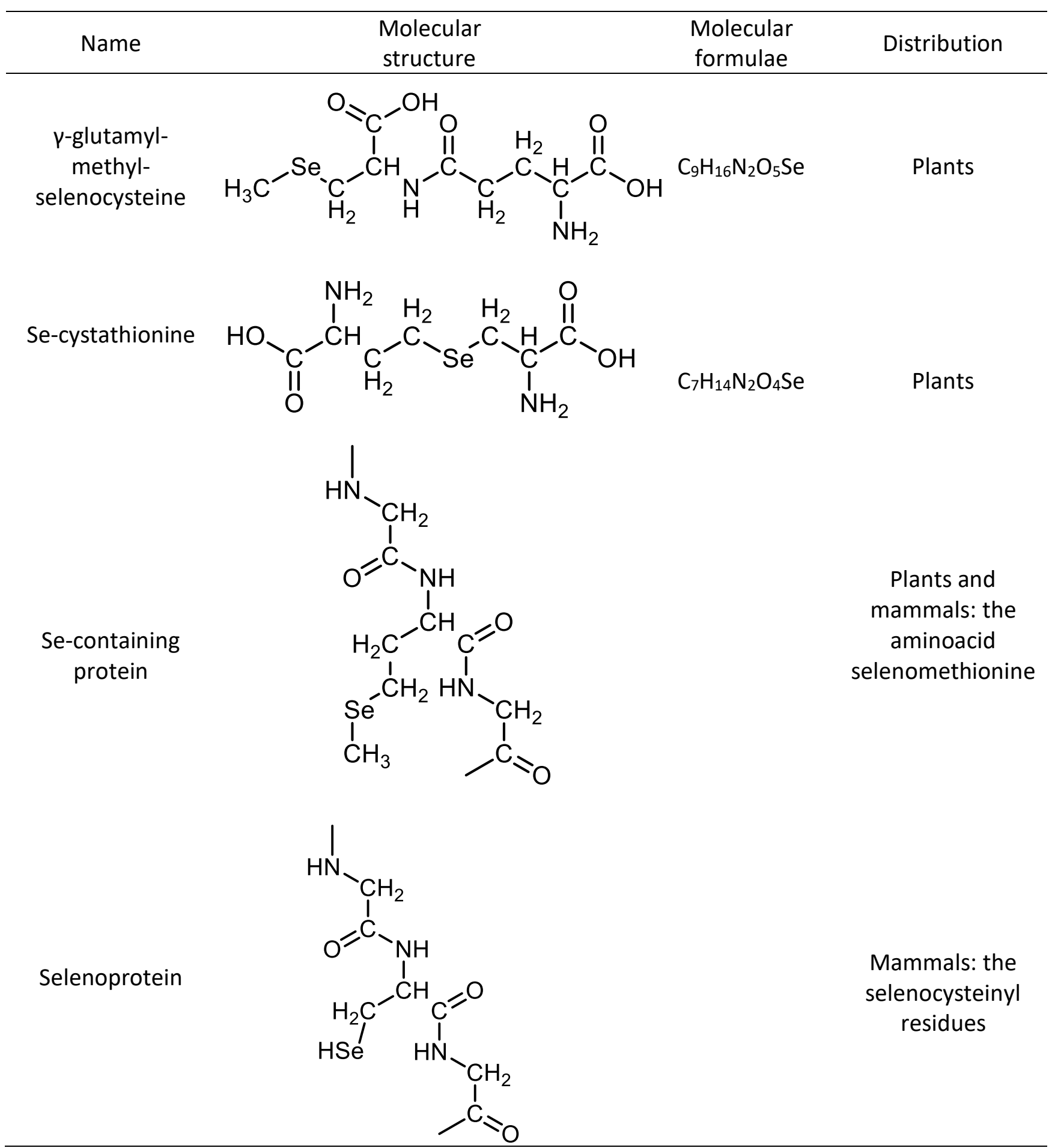

In mammals, the physiological chemistry of selenium is apparently played by a single functional group, i.e., the selenol (-SeH) group of a selenocysteinyl residues found in a few types of selenoprotein. ${ }^{4-14}$ The selenol (or selenohydryl) is an analog of the thiol (or sulfhydryl) group of cysteine and the or hydroxyl group found in serine (Figure 1). These functional groups have different roles in cell physiology and here we will focus on the properties of the selenol group. The general chemical structure of these amino acids is depicted in Figure 1. 


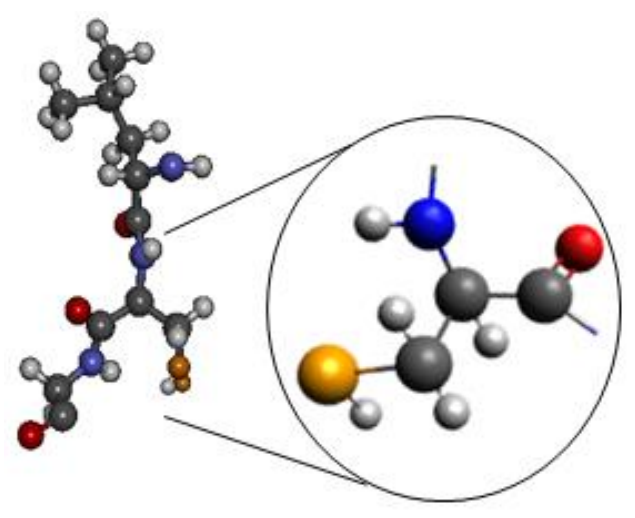

Selenocysteinyl

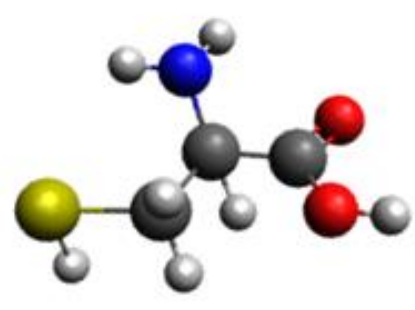

Cysteine

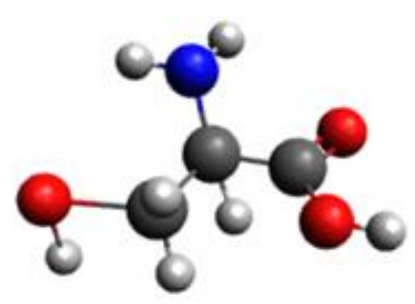

Serine

Figure 1. Structure of the naturally occurring amino acids with selenol, thiol and hydroxy groups.

Serine and cysteine can be found in body fluid as free amino acids in the low millimolar range (e.g., 0.05$0.2 \mathrm{mmoL} / \mathrm{L}){ }^{12}$ In contrast, selenocysteine is stable only inside the structure of selenoproteins and it cannot be detected in biological fluids as a free amino acid. The selenol group has lower redox potential than the analogous thiol group. ${ }^{13,14}$ Serine has 6 codons, cysteine has 2 codons and selenocysteine has only one codon (UGA, which normally is the termination codon in mRNA molecules coding a protein). The incorporation of selenocysteine in selenoproteins is co-translational and involves the participation of structural factors both from the mRNA structure and from specific proteins that interact in the ribosomes with the UGA codon ${ }^{5}$ (Table 3 ).

Table 3. Some biological and chemical properties of the lateral groups of the amino acids selenocysteine, cysteine and serine

\begin{tabular}{|c|c|c|c|}
\hline & L-Selenocysteine & L-Cysteine & L-Serine \\
\hline $\begin{array}{l}\text { Lateral group } \\
\text { (reduced forms) }\end{array}$ & $-\mathrm{SeH}$ & $-\mathrm{SH}$ & $-\mathrm{OH}$ \\
\hline $\begin{array}{l}\text { Lateral group } \\
\text { (oxidized forms) }\end{array}$ & $\begin{array}{l}\text {-Se-S- (selanyl-sulfide) } \\
\text {-SeOH (selenenic) }\end{array}$ & $\begin{array}{c}-\mathrm{S}-\mathrm{S}-\text { (dissulfide) } \\
-\mathrm{SO}_{2} \mathrm{H} \text { (sulfinic) } \\
-\mathrm{SO}_{2} \mathrm{OH} \text { (sulfonic) }{ }^{15-19}\end{array}$ & \\
\hline$p \mathrm{~K}_{\mathrm{a}}$ (lateral group) & $5.2^{13}$ & $8.3^{13}$ & \\
\hline Distribution in life & $\begin{array}{l}\text { Small number of } \\
\text { selenoproteins }\end{array}$ & Widespread & Widespread \\
\hline $\begin{array}{l}\text { Physiological role } \\
\text { outside protein }\end{array}$ & & Component of GSH ${ }^{15,21}$ & $\begin{array}{l}\text { Neurotransmitter } \\
\text { (D-Serine) })^{22-24}\end{array}$ \\
\hline Redox potential & $-488 \mathrm{mV}^{13}$ & $-233 \mathrm{mV}^{13}$ & \\
\hline Codon(s) & UGA & UGU and UGC & $\begin{array}{l}\text { UGA UCU, UCC, UCA, } \\
\text { UCG, ACG, and AGC }\end{array}$ \\
\hline
\end{tabular}

The human genome encodes 25 selenoproteins, but only about half of them present a definite biochemical role. ${ }^{5-11,14,25-30}$ A schematic representation of the chemical reactions catalyzed by well-studied selenoenzymes is depicted in Table 4. 
Table 4. Diagrammatic representation of the reactions of the seleno groups in mammalian cells ${ }^{27,28}$. For commentary and explanation see the paragraph that follows.

\begin{tabular}{|c|c|c|c|c|c|c|c|}
\hline No. & & eag & & & oduct & & Enzymes \\
\hline 1 & $\mathrm{R}-\mathrm{AeH}$ & + & $\mathrm{ROOH}$ & $\mathrm{R}^{1}-\mathrm{SeOH}$ & + & $\mathrm{ROH}$ & GPx \\
\hline 2 & $\mathrm{R}-\mathrm{SeOH}$ & + & GSH & $\mathrm{R}^{1}-\mathrm{SeSG}$ & + & $\mathrm{H}_{2} \mathrm{O}$ & GPx \\
\hline 3 & $\mathrm{R}^{1}-\mathrm{SeSG}$ & + & GSH & $\mathrm{R}-\mathrm{seH}$ & + & GSSG & GPx \\
\hline 4 & $\mathrm{R}_{-\mathrm{SH}}^{2-\mathrm{SH}}$ & + & $\mathrm{R}^{3-S}$ & & + & $\mathrm{R}^{3-\mathrm{SH}}$ & TrxR \\
\hline 5 & $\mathrm{R}^{3-\mathrm{SH}}$ & + & & & + & $\mathrm{SH}$ & TrxR \\
\hline 6 & $\mathrm{R}_{\mathrm{SeH}}^{4-\mathrm{SH}}$ & & $\mathrm{R}^{5} \stackrel{\mathrm{O}}{\|_{S}}-\mathrm{R}^{6}$ & $\mathrm{R}^{4-\mathrm{SH}}$ & + & $R^{5}-S-R^{6}$ & MsrB \\
\hline 7 & $\mathrm{R}$ & $S$ & $\mathrm{OH}$ & $\mathrm{R}^{4-S}{ }_{\mathrm{Se}}^{\mathrm{S}}$ & + & $\mathrm{H}_{2} \mathrm{O}$ & MsrB \\
\hline 8 & $v_{\mathrm{Se}}^{4-S}$ & + & $\begin{array}{l}\mathrm{SH} \\
\mathrm{SH}\end{array}$ & $\mathrm{R}_{\mathrm{SeH}}^{4-\mathrm{SH}}$ & + & s & MsrB \\
\hline 9 & $\mathrm{R}^{7}-\mathrm{SeH}$ & + & $\stackrel{\mathrm{I}}{\mathrm{R}}_{\mathrm{C}-\mathrm{R}}$ & $\mathrm{R}-\mathrm{7}-\mathrm{Se}-\mathrm{I}$ & + & 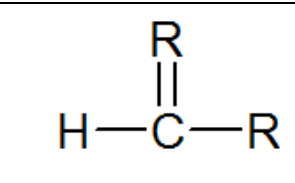 & Dio \\
\hline 10 & $\mathrm{R}^{7}-\mathrm{Se}-\mathrm{I}$ & + & $2 \mathrm{R}-\mathrm{SH}$ & $\mathrm{RS}-\mathrm{SR}+$ & $\mathrm{HI}$ & $+\mathrm{R}^{7}-\mathrm{SeH}$ & Dio \\
\hline
\end{tabular}

The reaction of peroxides with the selenol group can form either $\mathrm{H}_{2} \mathrm{O}$ or alcohols. In the living cell, reaction 1 indicated for $\mathrm{R}^{1}$-SeH is catalyzed by isoforms of glutathione peroxidase (GPx). The GPx isoforms reduce peroxides, using reduced glutathione $(\mathrm{GSH})$ as the source of reducing equivalents. Since $\mathrm{H}_{2} \mathrm{O}_{2}$ and organic peroxides $(\mathrm{ROOH})$ can react with $\mathrm{Fe}^{2+}$, forming extremely reactive intermediates (for instance, ${ }^{\circ} \mathrm{OH}$ and $\mathrm{ROO}^{\circ}$ ), the enzyme protects cells from the oxidative stress induced by peroxide metabolites. In reaction 2 , the Se atom of the selenenic acid is attacked by an S from the thiol group of a reduced GSH forming the -S-Sebond. This type of bond is central in the biological chemistry of selenium and illustrates the importance of sulfur-selenium interaction in cell biology. In reaction 3, a second molecule of GSH attacks the sulfur in the intermediate $-\mathrm{S}$-Se-, regenerating the $\mathrm{R}^{1}-\mathrm{SeH}$. The reactions catalyzed by the thioredoxin reductase (TrxR) isoforms are represented in reactions 4 and 5: first the $-\mathrm{S}$-Se- bond is reduced by two vicinal thiol groups, then the selenol and thiol group of TrxR reacts with the disulfide bond (-S-S-) found in the oxidized Trx, reducing it to the reduced Trx. In the methionine sulfoxide reductase (MsrB) (reactions 6 to 8), the selenol group of the enzyme is supposed to interact with the sulfur atom of the sulfoxide, the selenol group is oxidized to a selenenic acid and the methionine is regenerated (reaction 6). The thiol group of MsrB, which is in close 
proximity to a selenenic group in the active center of the enzyme, attacks this oxidized group, releasing $\mathrm{H}_{2} \mathrm{O}$ and forming a -S-Se- inside the active center of MsrB (reaction 7). The oxidized enzyme (-S-Se-) can be regenerated by reduced Trx (reaction 8). The sequence of reactions 4-9 demonstrate that the substrate of TrxR (i.e., the Trx) is important to maintaining the MsrB in its active form and indicate an intricate relationship among the selenoenzymes. The reactions 1-8 indicate that sulfur-selenium interactions are fundamental for selenoprotein physiological roles. Reactions 9 and 10 represent the steps of the reaction catalyzed by iodothyronine deiodinase (Dio) isoforms. In the first step, the selenol group of Dio attacks the C-I bond, forming the intermediate -Se-I. In the second step, an endogenous thiol (still not identified) regenerates the active Dio.

In this mini review, we will discuss basic aspects of the role of selenoproteins in cell physiology but will not give details about the discoveries that led to the establishment of selenocysteine as the twenty first amino acid. For a comprehensive view of this exciting field of selenium biology, we refer the reader to several important reviews and references (for instance, refs 31-33).

\subsection{The essentiality of selenium to life}

From the chemical point of view, life is based on carbon and on other relatively light elements bound covalently to carbon or existing as free ions in the aqueous environment of living cells (Figure 2). The exceptions are lithium, fluorine and beryllium that probably because of their size and reactivity could not be selected to exist in the living cell as ions. lodine is the heaviest element found in organic molecules in mammals, but it has a limited role as a component of the thyroid hormones 3,3',5,5'-tetraiodothyronine (thyroxine or T4) and by 3,3',5-triiodothyronine (T3). Selenium is the second heaviest element found covalently bound to carbon, but it has a much broader physiological role than iodine. Of note, the activation of T4 to T3, by 5'-deiodination, is catalyzed by the selenoenzyme iodothyronine deiodinase (Dio). The catalysis involves a direct interaction of selenium (as selenol group) with iodine $27,28,35,36$ (Table 4).

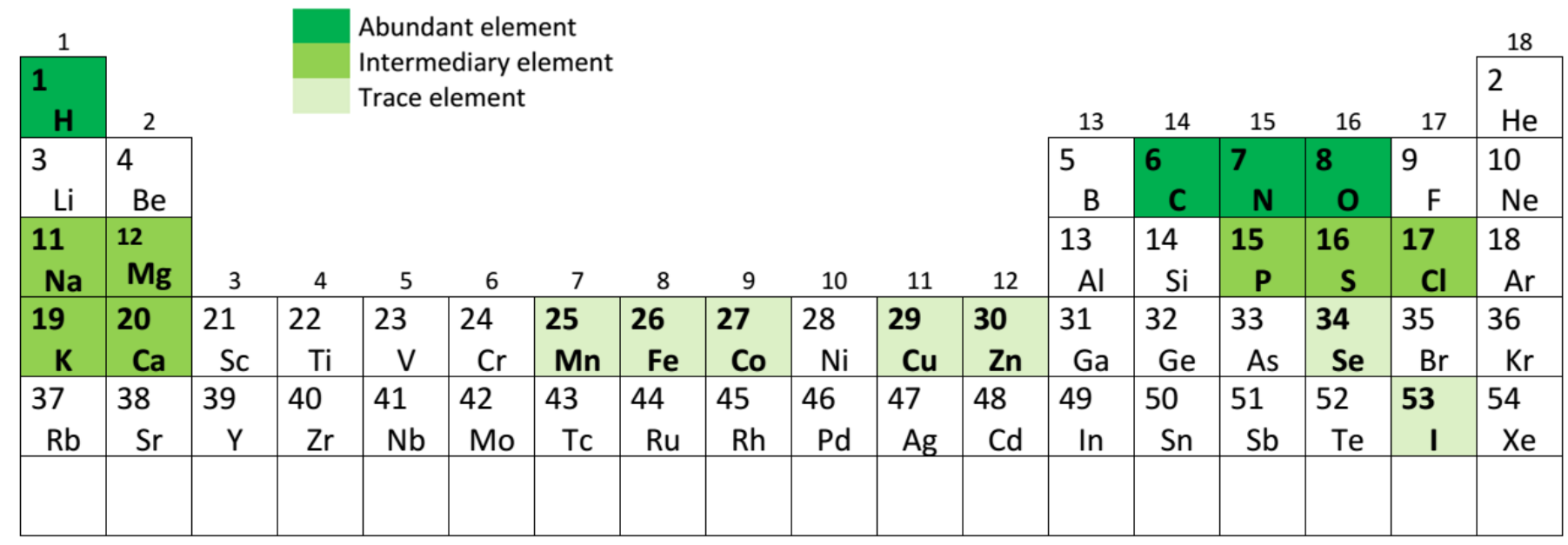

Figure 2. Essential elements in mammalian cell physiology.

The role played by selenium in life is much narrower than sulfur, which is found adjacent to selenium in the periodic table. In contrast to selenium, which is found only in selenocysteinyl residues $2,4-10,13,14,25-28,37,38$, sulfur is found in thousands of proteins as the thiol group of cysteine or as thioether group in methionine, 
either as part of methionine initiator tRNA or as internal residues of innumerable proteins. ${ }^{39-44}$ Thiolcontaining proteins can play a much more diverse catalytic role than selenol-containing proteins. ${ }^{40-43}$ The selenoenzymes are oxidoreductases that catalyze a narrow range of reactions. ${ }^{5,7-9,27-30,38}$ As cited above, the human genome encodes only 25 selenoproteins and the maximum number of selenoproteins found in vertebrates is about $40 .{ }^{45}$ The limited participation of selenium in the physiology of living cells indicates that the selenol group was selected by evolutional pressures to perform only a restricted set of chemical reactions. The restricted role of selenium in living cells and the negligible occurrence of the selenol group out of selenoproteins is certainly determined by the extreme reactivity of the selenol groups under physiological conditions. ${ }^{46,47}$ The unstable nature of the selenol group found in low molecular mass molecules has been recognized for a long time in pure chemical systems. ${ }^{48}$ In fact, the stabilisation of the selenol group can only be accomplished in the complex microenvironment of high molecular mass selenoproteins. ${ }^{28}$ In mammals, the precise fine tuned exploitation of selenium in cell biochemistry is further exemplified by the hierarchy of selenium utilization by different tissues under dietary selenium shortage. ${ }^{49-51}$ For instance, when compared with liver and other tissues, the brain is spared from selenium deficiency, indicating that evolutionary pressures have also modulated the preferential bioavailability of selenium to specific organs. ${ }^{51-53}$ Accordingly, the importance of selenoproteins for proper brain functioning has become much more apparent in the last decades. ${ }^{52-61}$

Two intriguing facts about the selection of selenium as a critical component of living cells are: 1 ) selenium is not essential to all forms of life; for instance, higher plants and fungi do not have selenoproteins; ${ }^{5,6,45}$ and 2) the thiol group found in the cysteinyl residues of thousands proteins could theoretically imitate the physiological chemistry of the selenol group. ${ }^{38,41-43}$ Consequently, one important question about the physiological chemistry of selenium is: why have some types of living cells been selected to have selenium as a part of their biochemical machinery?

Selenium (-SeH/-Se') can be a better nucleophile than sulfur (-SH/-S) in living cells and, consequently, catalyze more efficiently the reduction of biologically relevant chemical species, ${ }^{38,40,62}$ but this does not explain its absence in a large number of living organisms. Since the molecular logic of the living state assumes that living cells obey the principle of maximal economy, ${ }^{63}$ we can presume that the intricate complexity associated with the incorporation of selenium into the backbone of selenoproteins brought some adaptive biochemical properties that cannot be understood in simple redox chemical terms. ${ }^{64}$ The apparent conundrum about why selenium is essential only to some but not all living cells will require much more refined studies of the biochemical properties of the thiol and selenol groups of proteins from archea to mammals.

The objective of this minireview, compiled to mark the $80^{\text {th }}$ anniversary of Dr. Jacek Młochowski, who was a researcher dedicated to the synthesis of organoselenium compounds and one of the pioneers of research into their use as potential pharmacological agents, ${ }^{65-80}$ is not to offer the reader a comprehensive account of the importance of selenium in organic synthesis of pharmacologically active compounds, because this can be found in several comprehensive reviews. ${ }^{70,79-110}$ Here we give a brief historical account of the biological interest in selenium and its use in the synthesis of organoselenium compounds as biologically active molecules. We will discuss some critical points in the field that we realize are delaying the development of therapeutically effective agents. In terms of cell biology, we will present, in a brief way, the history of the biological interest in the element selenium, particularly how its incorporation into organic moieties has been important to life from a toxicological, pharmacological and physiological point of view. Although thousands (perhaps millions) of organoselenium compounds have already been synthesized since $1836 ;^{70}$ only a small portion of them have been tested in biological systems. In our opinion, the absence of high-throughput 
methods to investigate the toxicity of the countless number of newly synthesized organoselenium compounds on rational grounds is the main bottleneck to the development of organoselenium therapeutic agents. The critical and elegant review: "Organochalcogen as peroxidase mimetics as potential drugs: a long story of a promise still unfulfilled" by Orian and Toppo ${ }^{111}$ has recently addressed the necessity of new approaches to study the biology of organochalgogens. The development of in silico models to predict both thermodynamic parameters of intermediates stability and the interaction of organoselenium compounds with specific molecular targets are highly needed. Though the papers dealing with in silico simulation of organoselenium compounds chemical and biochemical behavior have been increasing, ${ }^{111-121}$ we are far from accomplishing the task.

\section{Chemical Interest in the Use of Selenium in Organic Synthesis}

\subsection{A brief history of the synthesis of organoselenium compounds}

Interest in the synthesis of organoselenium compounds goes back to the early $19^{\text {th }}$ century, when the first organoselenium compound was synthesized. According to Fredga, ${ }^{122}$ organoselenium chemistry started on January 23, 1847, precisely, when Wöhler wrote to Berzelius: "Today a small grandchild of yours has come in the world, a child of selenium, the selenomercaptan". The synthesized molecule was ethyl selenol (Table 5), prepared from calcium ethyl sulfate and potassium hydroselenide by Siemens. Siemens reacted the product of the reaction with $\mathrm{Hg}$ (II) to form $\mathrm{CH}_{3} \mathrm{CH}_{2} \mathrm{SeHgSeCH}_{2} \mathrm{CH}_{3}$ and proved that it was a "selenomercaptan". 123 However, according to Prof. Młochowski and collaborators, the synthesis of diethylselenide has priority, being reported in 1836 by Löwing. ${ }^{70}$

In Table 5 are listed the first selenium compounds synthesized by man and the first compound detected in mammalian metabolism by its smell. The ethyl-containing molecules were synthesized by man, ${ }^{70}$ whereas the dimethylselenide was discovered by the sense of smell of the early toxicologists, who evaluated the toxicity of inorganic selenium salts in mammals (see below in Section 3.1).

Table 5. Early historical landmarks in selenium chemistry

\begin{tabular}{|c|c|c|c|}
\hline Name & $\begin{array}{l}\text { Molecular } \\
\text { structure }\end{array}$ & $\begin{array}{l}\text { Molecular } \\
\text { formula }\end{array}$ & $\begin{array}{l}\text { Discovery/ } \\
\text { synthesis }\end{array}$ \\
\hline Diethylselenide & & $\mathrm{C} 4 \mathrm{H} 10 \mathrm{Se}$ & 1836 \\
\hline Ethylselenol & & $\mathrm{C} 2 \mathrm{H} 6 \mathrm{Se}$ & 1847 \\
\hline $\begin{array}{l}\text { Diethyldiselenide } \\
\text { mercury }\end{array}$ & & $\mathrm{C} 4 \mathrm{H} 10 \mathrm{HgSe} 2$ & 1847 \\
\hline Dimethylselenide & & $\mathrm{C} 2 \mathrm{H} 6 \mathrm{Se}$ & 1894 \\
\hline
\end{tabular}


The book "The organic compounds of tellurium and selenium belonging to the alcohol series" by Dean, 124 who had worked in the laboratory of Wöhler, emphasizes the similarity between S, Se, and Te. By paraphrasing the author: "In regard to the history of these compounds it may be observed, that the extraordinary resemblance between sulfur, selenium, and tellurium first led to the idea of substituting selenium or tellurium for sulfur in various organic compounds...", we can realize that at a very early stage of organic synthesis development, selenium was being investigated as surrogate for sulfur. As briefly commented in the first section of this mini-review, biological evolution has apparently endeavored to substitute sulfur by selenium at an early stage of the evolution of a living cell. With the introduction of selenium in the biochemical machinery, the living cell gained efficiency in metabolizing important redox reactions, 5,17,38,40 whereas the synthetic chemist gained versatility in their reactions. ${ }^{65,70,81-103}$

One important limitation in the early years of organoselenium compound synthesis was the availability of selenium. ${ }^{124}$ Regardless of the unavailability of the element in the $19^{\text {th }}$ century, the field progressed considerably. In his classical review from 1941, Edgar P. Painter stated that hundreds of organoselenium compounds had been described and presented a list of the available synthetic strategies to prepare diselenides, selenols, selenenic, and selenonic acids, among others. ${ }^{48}$ Recent literature considers that modern era of organoselenium synthesis began in the seventies of the last century. ${ }^{1,70}$ The organic chemical interest in selenium is associated with its ability to confer to the organic moiety enormous chemical versatility. ${ }^{81-99}$ The importance of this element in the field of organic synthesis can be verified by the vast literature on organoselenium chemistry. From Painter's time to the present, we can roughly estimate the number of new organoselenium compounds synthesized every year and now thousands to millions of compounds can be found in the literature.

\subsection{Re-discovery of Ebselen: can the chemist imitate chemistry of life?}

The general chemical interest in the synthesis of new organoselenium compounds boomed after the clinical use of 2-phenyl-1,2-benzisoselenazol-3(2H)-one or Ebselen. ${ }^{125-127}$ Ebselen was originally synthesized in 1924 by Lesser and Weiss ${ }^{128}$ and it was re-discovered as an antioxidant about 40-50 years ago (for an interesting testimony about the development of Ebselen as a therapeutic agent see refs 129,130 ) (Table 6). Ebselen is the most popular organoselenium compound and it was subjected to clinical trials about 20 years ago with borderline efficacy. ${ }^{125-127}$

Table 6. The Structure of some organoselenium compounds with interesting pharmacological properties

\begin{tabular}{|c|c|c|}
\hline Name & $\begin{array}{l}\text { Molecular } \\
\text { structure }\end{array}$ & Molecular formulae \\
\hline Tetrahydroselenophene & 12 & $\mathrm{C}_{4} \mathrm{H}_{8} \mathrm{Se}$ \\
\hline $\begin{array}{c}\text { Ebselen } \\
\text { (2-Phenyl-1,2- } \\
\text { benzoselenazol-3(2H)- } \\
\text { one) }\end{array}$ & 0 & $\mathrm{C}_{13} \mathrm{H}_{9} \mathrm{NOSe}$ \\
\hline
\end{tabular}


Table 6. Continued

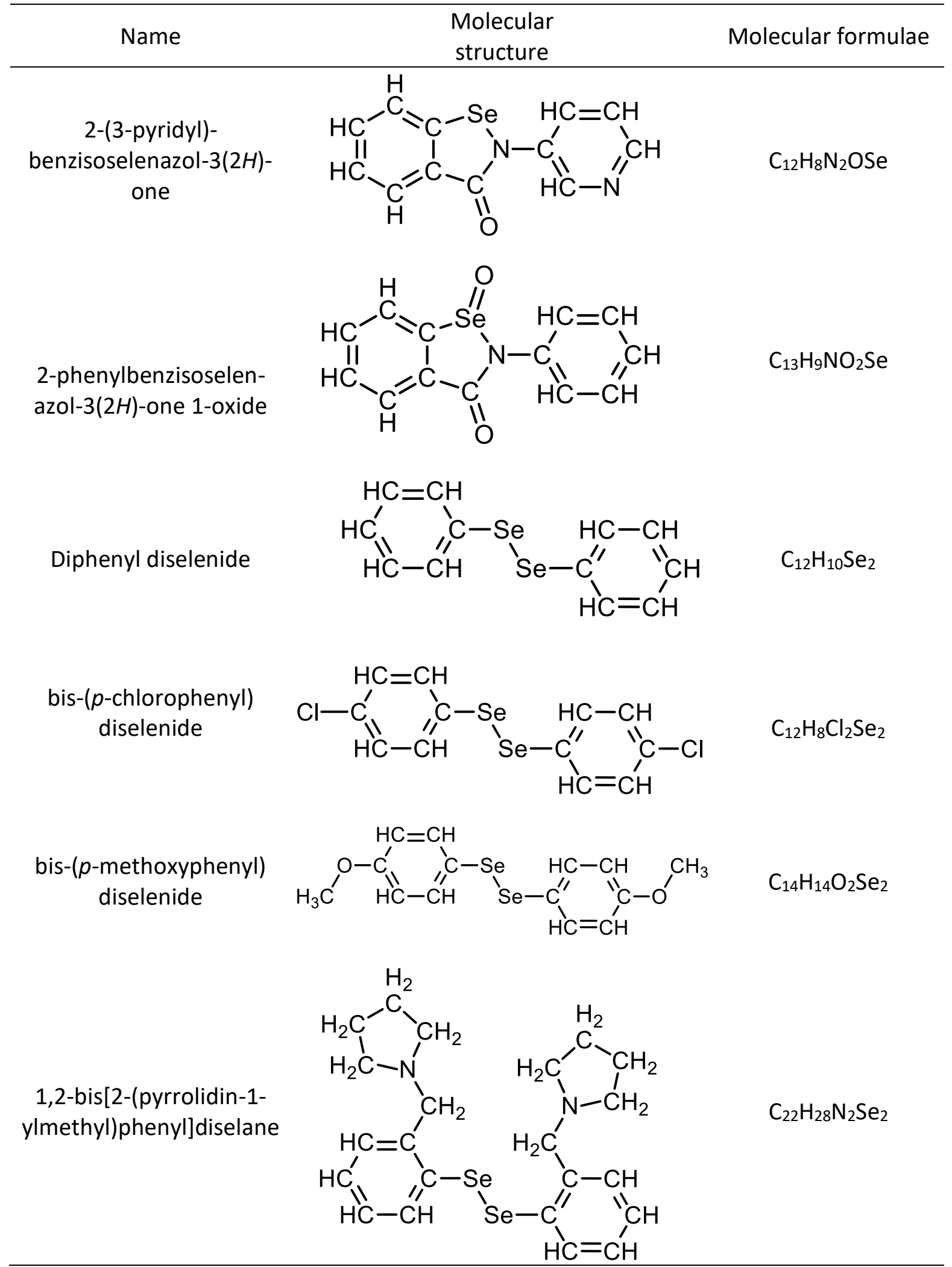

The use of Ebselen in clinical trials to treat brain pathologies associated with oxidative stress changed the view of selenium compounds. As stated in their vivid report about the steps that led to the development of Ebselen as therapeutic agent, the first goal was to use Ebselen as a source of selenium for the synthesis of 
selenoproteins. The discovery of selenium in the structure of gluthathione peroxidase (GPx) and its role in peroxide degradation ${ }^{131,132}$ had introduced the idea that selenium supplementation could be an important strategy to improve the activity of GPx. The rationale that Ebselen could be a better source of selenium than inorganic selenium or naturally occurring organic selenium forms can be easily understood by the fear of selenium (selenophobia) that was prevalent in the $20^{\text {th }}$ century ${ }^{133}$ (the history of selenium toxicity to mammals will be presented in the next section of this review). Contrary to the expectation of the researchers, ${ }^{129}$ the selenium in Ebselen was not metabolized to the inorganic selenium pool, which would be required for selenium incorporation into selenocysteine (i.e., into selenoproteins; ${ }^{5}$ Figure 1). But Ebselen exhibited several interesting antioxidant properties, including the ability to mimic the activity of GPx (glutathione peroxidase- or thiol peroxidase-like activity). ${ }^{134-136}$

After that, the GPx- or thiol peroxidase-like activities of organoselenium compounds have been alleged to be the most important mechanism involved in the pharmacological effects of various organoselenium compounds (Table 4, reactions 1 and 2), regardless of the low catalytic efficiency of simple organoselenium compounds in accelerating the decomposition of peroxides. ${ }^{135-137}$ The basic mechanism of peroxide decomposition by organoselenium compounds (e.g. Ebselen and diselenides, Table 6), which forms selenol intermediates, ${ }^{101,104}$ is supposed to be similar to that of the native GPx isoforms (Scheme 1). Other selenium compounds that are not metabolized to selenol intermediates (for instance, tetrahydroselenophenes, Table 6) can also mimic the activity of GPx by forming a selenoxide intermediate after decomposing peroxides. ${ }^{81}$
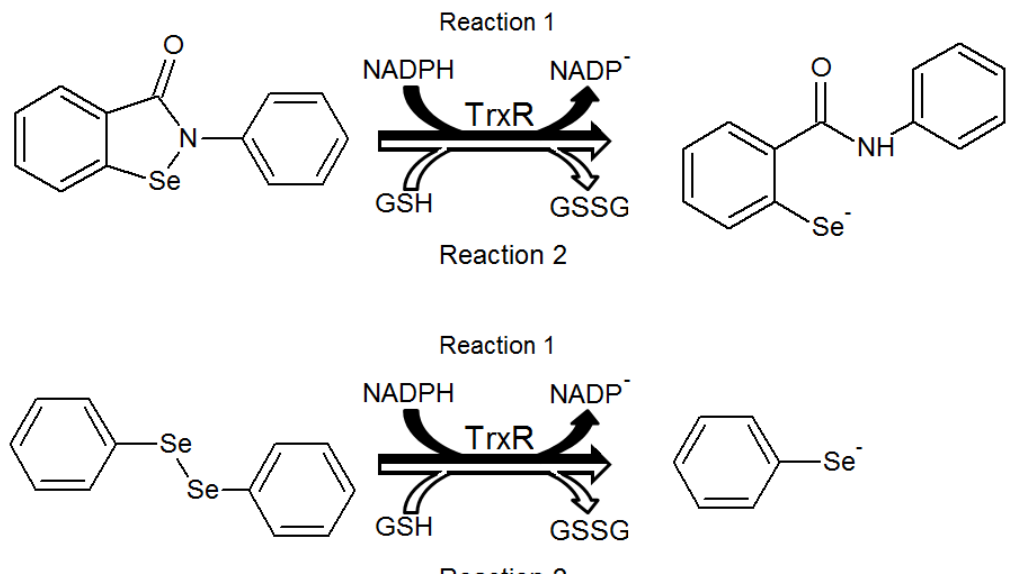

Reaction 2

Scheme 1. Reduction of Ebselen and diphenyl diselenide to selenol intermediates. Reaction 1 is catalyzed by thioredoxin reductase (TrxR) and uses NAPDH as an electron donor. Reaction 2 uses glutathione (GSH) as an electron donor.

Ebselen and diphenyl diselenides can be reduced to selenol intermediates both after reacting directly with thiol-containing molecules or after being reduced by $\operatorname{TrxR}^{138-140}$ (Scheme 1). Literature studies have also indicated that organoselenium compounds can interact with specific thiol-containing proteins. ${ }^{141,142}$ Ebselen and diphenyl diselenide have been reported to inhibit the activity of important metabolic enzymes in vitro, for instance, $\mathrm{Na}^{+}, \mathrm{K}^{+}$-ATPase, ${ }^{101,104,108}$ but there is no evidence that they can target it after in vivo administration. The inhibition of such a crucial enzyme can have unpredictable toxicological effects, particularly to the central nervous system. The specific interaction of Ebselen with inositol monophosphatase (IMPase) has been 
suggested to be involved in the lithium mimetic activity of Ebselen ${ }^{143}$ and can be involved in the antidepressive activity of Ebselen in experimental models. ${ }^{144}$ In contrast, diphenyl diselenide, which exhibited similar antidepressive activity in rodent models, is not an inhibitor of IMPase. ${ }^{143}$ The oxidation of thiol-containing proteins by organoselenium compounds can be involved both in their pharmacological and toxicological effects. The chemical mechanism of oxidation of thiol-containing proteins by organochalcogens is similar to that presented in Table 4 (reaction 1), where the thiol group of the protein substitute GSH as reducing agent. Theoretically, the oxidation of a therapeutically important protein by an organochalcogen can both cause a specific physiological effect and can generate the selenol intermediates. The selenol intermediate can then decompose peroxides and exhibit antioxidant properties.

Of particular importance for the pharmacological properties of Ebselen and diphenyl diselenide, the oxidation of antioxidant response elements (AREs), particularly the Nrf-2 ${ }^{145-149}$ (a transcript factor regulated by Keap 1) by organoselenium compounds have been suggested to participate in the antioxidant effects of Ebselen and diphenyl diselenide. ${ }^{150-157}$ For instance, the oxidation of Keap-1 by organoselenium compounds can activate the Nrf-2-transcript factor that stimulates the expression of antioxidant proteins. In summary, the pharmacological or toxicological effects of organoselenium compounds include the oxidation of thiol groups and from the chemical point of view, the basic mechanisms of reaction are similar to those presented by the selenoproteins.

\section{Biological Interest in Selenium: a Brief Historical Account}

\subsection{Early history of inorganic selenium toxicology}

From a historical point of view, the interest in the chemistry and toxicology of inorganic selenium (salts, oxides, acids) led to the first and vague connection between selenium as a toxic agent in mammals and the beginning of organoselenium compound synthesis. ${ }^{158-162}$ Some years after the isolation of selenium by Berzelius in 1817, the scientific community started to investigate both the synthesis of organoselenium compounds and the toxicity of inorganic selenium forms to living organisms. ${ }^{158-162}$

Although citations found in the English literature have some incongruent data about the studies published in German 3,159,161,165 the investigations performed between 1820 to 1950 (both with mammals and bacteria) were instrumental in demonstrating that living cells can reduce selenate (Se(VI)) and selenite (Se(IV)) to elemental selenium and some volatile form of organic selenium. ${ }^{159-165}$ According to Charles Jones, ${ }^{159}$ the first author to study the toxicity of selenium salts in animals was C. G. Gmelin. However, Moxon and Morris, ${ }^{3}$ in their classical review on "selenium poisoning", argued that they could not find experiments related to the toxicity of selenium in Gmelin's book. Gmelin studied the toxicity of tellurium salts ${ }^{160}$ and the source of confusion can be derived from the similar chemical and biochemical behavior of selenite and tellurite in bacteria and mammals, i.e., both salts can be reduced to elemental forms. ${ }^{156,159,164,165}$ Jones stated that Hasen (1853) described selenium granules deposited in the organs of animals injected with selenite and identified a garlic-like odor in the breath of poisoned animals; but apparently Hansen injected tellurite and not selenite. The chemical nature of the volatile compound(s) with garlic odor was supposed to be either dimethyl selenide or diethyl selenide ${ }^{159}$ (in fact, dimethyl telluride or diethyl telluride). In 1909, Jones demonstrated the deposition of a brick-red precipitate in the organs of animals intoxicated with selenite, but he concluded that the formation of elemental selenium was not the cause of the death of intoxicated animals, ${ }^{159}$ because he could observe comparable selenium granules in animals treated with high but non-lethal doses of selenite. The participation of hydrogen selenide (i.e., $\mathrm{H}_{2} \mathrm{Se}$ ) as a toxic metabolite of $\mathrm{Se}(\mathrm{IV})$ or $\mathrm{Se}(\mathrm{VI})$ was not considered 
by Jones, though hydrogen selenide was known to cause some signs of intoxication similar to those caused by lethal intoxication with selenite. ${ }^{158,159}$

Jones also observed a garlic-like odor in the breath of poisoned mammals. The emanation of garlic-like odor could also be detected in the organs isolated from animals poisoned with $\mathrm{Na}_{2} \mathrm{SeO}_{3}$. The proposal that the garlic-like odor present in the breath of selenium-poisoned animals was produced by dimethyl selenide was made by Hofmeister. ${ }^{159,165} \mathrm{He}$ injected sodium tellurite and detected the odor similar to dimethyl sulfide and postulated that exhaled compound after administration of tellurite was dimethyl telluride. Based on the chemical similarity between selenium and tellurium, Hofmeister speculated that the garlic-like odor detected after selenite intoxication was produced by dimethyl selenide. ${ }^{165}$ However, a conclusive demonstration that inorganic selenium exposure was associated with dimethyl selenide exhalation was made by McConnell and collaborator. ${ }^{165}$ The research work concerning the toxicity of selenium and tellurium salts carried out in the second half of the $19^{\text {th }}$ century were crucial to establish the first metabolic pathway of selenium in mammals (Scheme 2). The elucidation of the chemical nature of the first metabolically produced organoselenium molecule was confirmed only at the end of the second half of the $20^{\text {th }}$ century. ${ }^{164,165}$ The complete reductive pathway of $\mathrm{Se}(\mathrm{IV})$ and $\mathrm{Se}(\mathrm{VI})$ to selenide $\left(\mathrm{Se}^{2-}\right)$ was studied in different laboratories. ${ }^{159,161,164-168}$ Of particular importance to the physiological chemistry of selenium, selenide $\left(\mathrm{Se}^{2-}\right)$ is the unique chemical form of selenium metabolized to selenophosphate $\left(\mathrm{HPSeO}_{3}{ }^{2-}\right.$ or selenophosphoric acid, $\mathrm{H}_{3} \mathrm{PSeO}_{3}$ ), which can then be incorporated into the backbone of selenocysteine. ${ }^{5}$

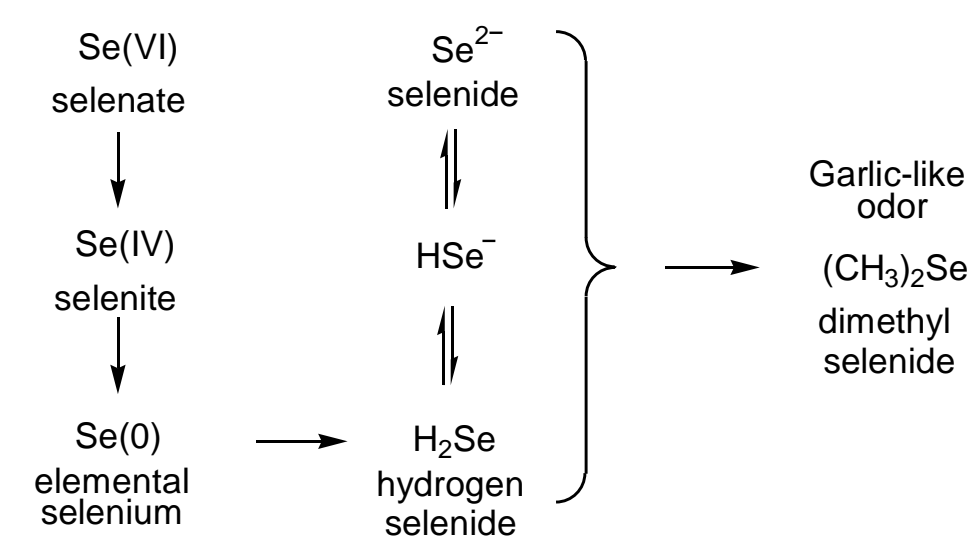

Scheme 2. Formation of $\mathrm{Se}(0)$ and volatile organic selenium after reduction of selenate or selenite in living cells.

The formation of elemental selenium was evidenced by the formation of brick-red selenium precipitate in the organs of animals intoxicated with selenium salts. The formation of organic selenium (dimethylselenide) was hypothesized by analogy with tellurite metabolism and by sensorial identification of a garlic-like odor in the breath of living intoxicated animals or by the release of garlic odor from their isolated organs. The formation of dimethylselenide was dissociated from the formation of $\mathrm{Se}(0)$ by Jones. ${ }^{159}$ He demonstrated that heating the organs up to $60{ }^{\circ} \mathrm{C}$ suppressed the formation of the garlic odor $\left[\left(\mathrm{CH}_{3}\right)_{2} \mathrm{Se}\right]$, but did not stop the formation of elemental Se. Jones concluded that carbohydrates, for instance, glucose reduced the selenite to elemental selenium. However, nowadays we know that the thiol group from glutathione and proteins are responsible by the chemical reduction of selenite to elemental selenium. 


\subsection{Oxidation of thiol groups and toxicity of inorganic selenium forms}

Our understanding of the toxicology of inorganic selenium is still elusive, however the oxidation of thiolcontaining molecules by cationic selenium ions is involved in the process of toxicity as macroscopically demonstrated by the early toxicologists. ${ }^{158,159}$ The reduction of Se(IV) and Se(VI) to elemental selenium by isolated organs from animals poisoned with selenite, forming brick-red precipitates, was possible even at high temperatures. ${ }^{159}$ This observation strongly indicates that selenate and selenite can be chemically reduced to elemental selenium (i.e., without the participation of heat-sensitive enzymes). Accordingly, selenite can oxidize $\mathrm{GSH}^{169}$ and the depletion of this important antioxidant molecule may cause toxic consequences to cells. ${ }^{170,171}$ The oxidation of GSH by Se(IV) and Se(VI) produces a disulfide bond, for instance oxidized glutathione (GSSG), and an intermediate containing -S-Se-S- interactions. ${ }^{172}$ Furthermore, during the oxidation of thiol groups by inorganic salts of selenium, reactive oxygen species can be formed and an excessive formation of these species can be deleterious to cells. ${ }^{173-175}$ Selenite and selenate can also oxidize the thiol groups of proteins, disrupting various cellular processes. ${ }^{173,174,176-180}$

\subsection{The therapeutic use of inorganic selenium}

After the demonstration of selenite and selenate toxicological properties, elemental selenium was used in the treatment of inoperable carcinoma. ${ }^{181-183}$ According to Watson-Williams, ${ }^{181}$ the rationale for administering selenium suspensions to human was based on the previous successful use of the element in animal models of cancer. Additionally, Watson-Williams ${ }^{181}$ stated that "injections of colloidal selenium had been used in human patients with inoperable carcinoma" in France. Selenium either alone or in combination with other therapeutic agents exhibited beneficial effects in a great proportion of patients with inoperable tumour. ${ }^{181-183}$ Nonetheless, the use of colloidal selenium was abandoned, possibly because its efficacy was not confirmed and/or in view of the increasing awareness of the toxicology of selenium at those times (see for instance refs 3 and 133). The fear of the element, which had escalated around the '30s to '60s, was so prevalent that Frost and Olso ${ }^{133}$ coined the term "selenophobia" to express the negative view of selenium.

The therapeutic use of elemental selenium in patients indicated that $\mathrm{Se}(0)$ was well tolerated by humans after systemic administration. Contrasting with the results obtained with Se(IV) and Se(VI), which indicated extreme toxicity in mammals, ${ }^{159}$ elemental selenium seemed to be relatively inert in humans. More recently, the use of synthetic and naturally occurring organoselenium compounds has been reconsidered as nutritional anti-cancer agents. ${ }^{184-189}$ However, the main results of an extensive study, in which selenomethionine and vitamin E were used as nutritional supplements, did not indicate a protective role for selenium against cancer. ${ }^{190,191}$ In contrast, some meta-analysis studies have supported a protective role of selenium in some types of cancer. ${ }^{192,193}$ The discrepancies between studies can be related to important factors, such as the basal level of selenium in the sample populations, genetic factors, the chemical form of selenium used in the studies with selenium supplementation, amongst others. ${ }^{191,194-196}$ Literature data have indicated that intake of selenium beyond the required nutritional level (here interpreted as that needed to support the ideal selenoprotein synthesis) can increase the incidence of some types of cancer and other chronic degenerative diseases, such as type 2 diabetes and amyotrophic lateral sclerosis (ALS). ${ }^{197-200}$ However, there are also indications that high levels of toenail Se is associated with a lowered risk of developing type 2 diabetes. ${ }^{201,202}$ 


\subsection{The toxicology of naturally occurring organoselenium compounds: selenium as a causative factor of livestock poisoning}

At the same time that elemental selenium was being used clinically to relieve the malady associated with different types of inoperable carcinomas, ${ }^{181-183}$ researchers in the USA were revealing the central role of "naturally-occurring selenium" as the causative factor of alkali disease in livestock.3,48,203-206 The studies of Franke and collaborators demonstrated that grains grown in regions previously associated with alkali disease had an elevated level of selenium and showed that the extraction of selenium from the plants abolished their toxicity. ${ }^{203-206}$ Franke and collaborators were also the pioneers in demonstrating that selenite could reproduce the majority of toxic symptoms caused by the ingestion of plants containing high levels of selenium. Additionally, Franke and Painter ${ }^{193} 207-211$ found that the removal of selenium from toxic protein hydrolysates abolished the toxicity of wheat protein. Some important chemical forms of naturally occurring Se are presented in Tables 1 and 2. In the case of the Franke and Painter studies, ${ }^{209-210}$ the main toxic form can retrospectively be ascribed to an organic form of selenium, for instance, selenomethionine and methylselenocysteine. ${ }^{212,213}$ Selenium accumulator plants can synthesize different organoselenium compounds, which can have toxicological properties, but little is known about the metabolism and toxicity of different combination of organoselenium compounds found in grain and vegetables.

The toxicity of naturally occurring selenium in livestock (alkali disease) has been associated with changes in the structure of hair, loss of long hair, and softening of hooves. 3,48,203-206 Chronic ingestion of a high level of selenium by humans can also cause similar modification in hair (including hair loss or alopecia) and in toenail structure. ${ }^{214-218}$ Here we should point out that keratin proteins, which are the key structural components of hair, hooves and nails, have a high cysteine content. ${ }^{219}$ The disruption of keratin-containing hair, hooves and nails by selenium intoxication demonstrate a tropism of selenium metabolites in cells that synthesize proteins rich in cysteine. The incorporation of selenium in secretions from keranocytes can be attested by the high content of the element in hair and nail. ${ }^{220,221}$

Although the toxicity of naturally occurring organoselenium compounds is not coincident with that of the inorganic salts, the oxidation of low and high molecular mass thiol molecules can also be involved in their toxicity. However, our knowledge about the selenium metabolites involved in the oxidative toxicity of different naturally occurring selenium compounds is still elusive. As observed with inorganic selenium forms and synthetic organoselenium compounds, ${ }^{222-226}$ the interaction of naturally occurring selenium compounds with endogenous thiol can generate reactive oxygen species (ROS) by mechanisms not well-defined at the molecular level. ${ }^{174-176}$

\section{The Biological and Pharmacological Interest in Synthetic Organoselenium Compounds: an Overview}

\subsection{The early pharmacological and nutritional use of synthetic organoselenium compounds}

Interest in the potential biological, pharmacological and, optimistically, therapeutic exploitation of synthetic organoselenium compounds started several decades ago, when organic forms of selenium were tested as potential anticancer agents. In 1941, diselenane-diacetic acid $\left(\mathrm{HO}_{2} \mathrm{CCH}_{2}-\mathrm{Se}-\mathrm{Se}-\mathrm{CH}_{2} \mathrm{CO}_{2} \mathrm{H}\right)$, diselenane-ndibutyric acid $\left[\mathrm{HO}_{2} \mathrm{C}\left(\mathrm{CH}_{2}\right)_{3}-\mathrm{Se}-\mathrm{Se}-\left(\mathrm{CH}_{2}\right)_{3} \mathrm{CO}_{2} \mathrm{H}\right]$, and mercurybis(4-selenobutyrate) $\left[\mathrm{HO}_{2} \mathrm{C}(\mathrm{CH})_{3}-\mathrm{Se}-\mathrm{Hg}-\mathrm{Se}-\right.$ $\left(\mathrm{CH}_{2}\right)_{3} \mathrm{CO}_{2} \mathrm{H}$ ] were tested in tumor-bearing mice (Table 7). ${ }^{227}$ The authors stated that selenium compounds appeared interesting to be tested in view of their relationship with sulfur metabolism; however, the authors assessed the distribution of selenium, but did not present data about the potential anti-tumor effect of the 
different compounds tested. In more recent years organoselenocyanate compounds have been extensively studied as anticancer agents. ${ }^{228-231}$ Though this class of compound has been shown to exhibit beneficial effects in vitro and in vivo against cancer (Table 7), they were not put through clinical trials.

Table 7. Organoselenium compounds with anti-tumorogenic potential

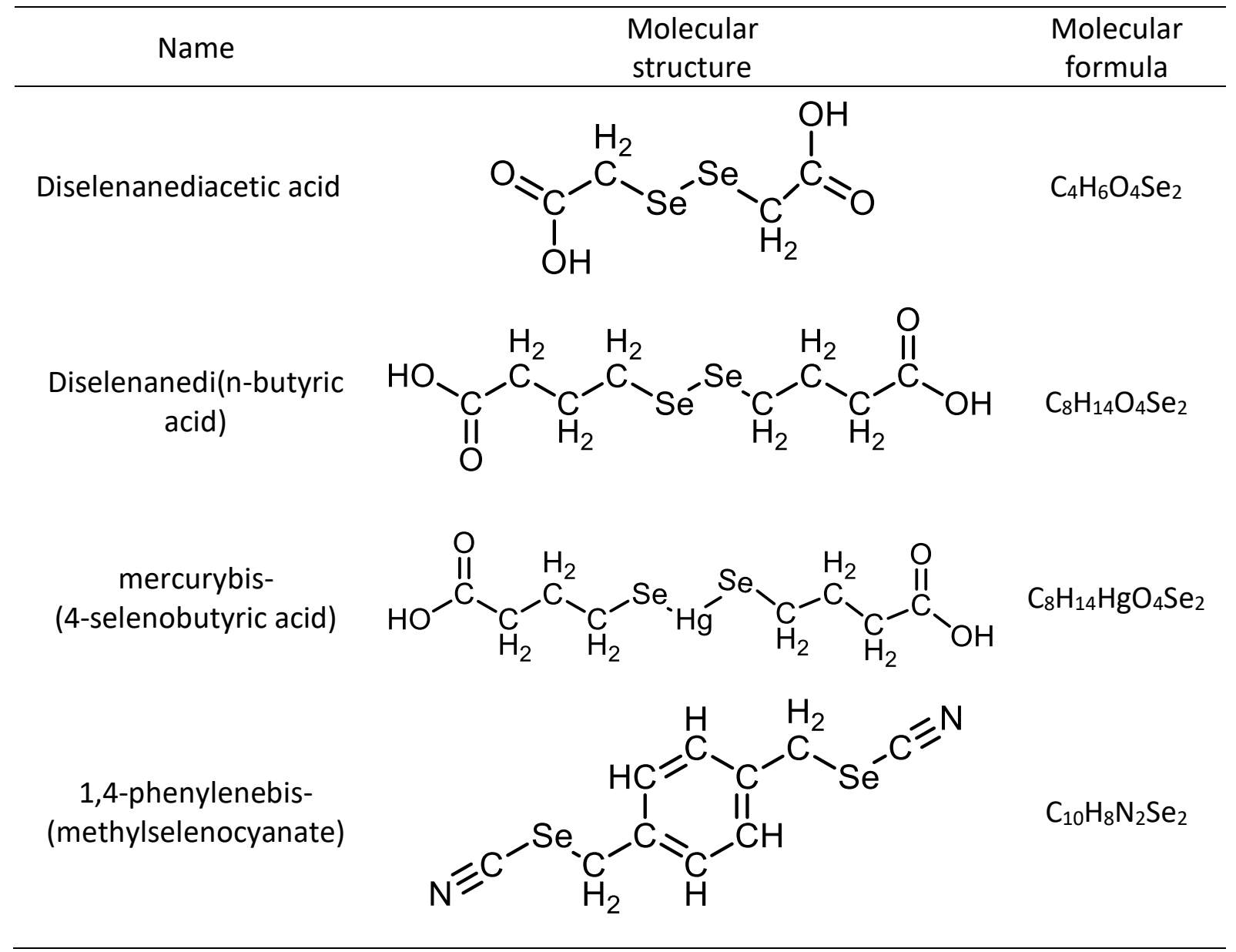

In addition to the potential anticancer properties, organoselenium compounds have been shown to exhibit interesting pharmacological properties in different experimental models of human pathologies. Of note, they can have antioxidant, neuroprotective, anti-inflammatory, antidepressive, imunomudulatory, antimicrobial activity against pathogenic bacteria, fungi and viruses, among others ${ }^{14,64-91,232-239}$.

The effectiveness of some organoselenium compounds as beneficial agents in quite different acute or chronic models of human degenerative disease can be explained by their anti-inflammatory and antioxidant properties. The molecular processes involved in a variety of human pathologies have in common the production of inflammatory mediators (for instance, diabetes, Alzheimer disease, Parkinson disease, ischaemia, atherosclerosis). ${ }^{239-249}$ The inflammatory processes stimulate the over production of reactive species (e.g. reactive oxygen (ROS) and nitrogen species(RNS)) and these will further stimulate the release of pro-inflamatory molecules (Scheme 3). 


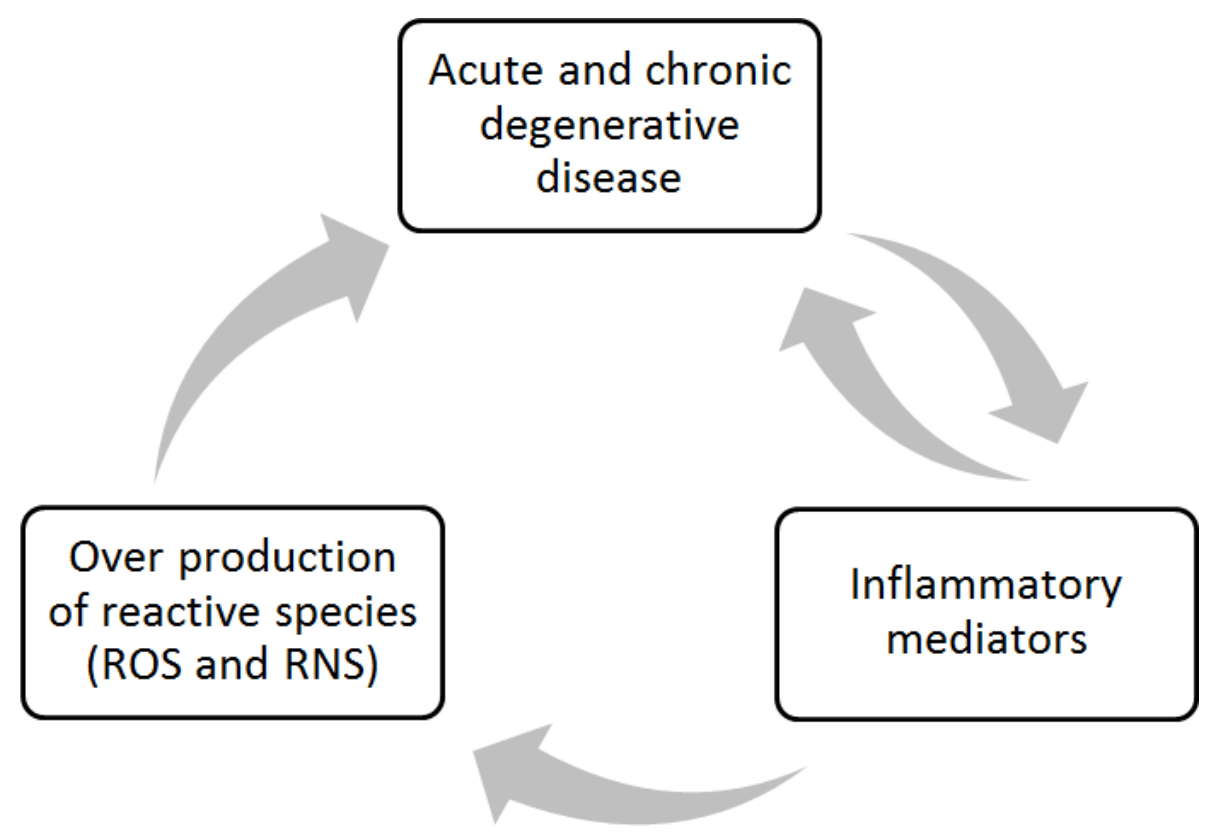

Scheme 3. Interplay between inflammation, oxidative stress and human diseases.

Although Scheme 3 is an oversimplification of a rather complicated processes, the modulation of peroxide tonus by organoselenium compounds can decrease the release of pro-inflammatory mediators indirectly. A direct anti-inflammatory role of some organochalcogens is also possible plausible, but this has not yet been investigated in detail. The fact that organoselenium compounds exhibit protective effects in a variety of models of diseases with different etiologies argues in favor of quite general mechanism of action. The GPx-like or thiol peroxidase-like activity can explain the general beneficial effects of organoselenium compounds. For the case of Ebselen and diphenyl diselenide, the GPx-like activity is thought to be mediated by the formation of selenol intermediates. In view of the simple structure of the organoselenium compounds cited above we can predict that the selenol intermediates formed will not present selectivity. The selenol intermediates will be able to mimic the physiological chemistry of selenoproteins in general, and not only of GPx isoforms. However, we have only a vague idea about the efficacy of organochalcogens to mimic specific selenoproteins. Another important mechanism that seems to be involved in the beneficial effect of organochalcogens is their capacity to function as weak electrophiles. Various laboratories have provided data supporting these assumptions. ${ }^{150-157}$

The mechanism of action of the most studied organoselenium compounds is thought to involve antioxidant and anti-inflammatory properties and the ability of activate the expression of antioxidant genes. ${ }^{100-110,150-157}$ Here we discuss one important mechanism that has been neglected in the recent literature about the beneficial effects of some synthetic organoselenium compounds. The studies in question were published about 60 years ago and just one year after the appearance of the most well-known paper about the biological importance of selenium. ${ }^{250,251}$ The proximity of the two publications of Schwartz and Foltz obscured the importance of the second study. In this classical study from 1958, Schwarz and Foltz clearly demonstrated that different mono- and diselenides prevented dietary liver necrosis in rats fed with a vitamin E deficient diet. $^{250}$ The new data extended the results obtained by the same authors one year before, in which they demonstrated that factor 3 (a nutritional factor isolated from the yeast or the kidneys of pig) had selenium as the active principle. ${ }^{251-253}$ Factor 3, which was identified as an organoselenium compound, and selenite prevented liver degeneration induced by a diet deficient in vitamin $\mathrm{E}$ in rodents. ${ }^{250-253}$ These studies provided 
the first experimental demonstration that both inorganic and organic selenium compounds had hepatoprotective effects in rodents. Taken together with the study of Adams and collaborators, ${ }^{254}$ which showed the release of selenium from the organic moiety of diphenyl diselenide, the studies of Schwartz and collaborators ${ }^{250,255}$ indicated that simple organoselenium compounds such as aliphatic diselenides, diphenyl diselenides and diphenyl selenides can furnish selenium to the inorganic pool of selenium. The inorganic selenide released from aromatic and aliphatic selenides can be used in the synthesis of selenoproteins. Thus, in part, the beneficial effects of organoselenides can be related to modulation of selenoprotein synthesis.

The clinical trials with Ebselen in the '90s have indeed powered the field of synthetic organoselenium compounds, despite the fact that the Japanese authorities did not approve its use in the treatment of brain ischaemia. ${ }^{125-127,129,130}$ Ebselen is now included in the chemical library of the National Institutes of Health Clinical Collection as a safe drug, ${ }^{143}$ but without a target pathology to treat. The interest in finding a target for Ebselen has increased considerably in the last ten years and it is now being studied as a potential lithium mimetic in humans, ${ }^{143,256-259}$ experimentally as an antimicrobial agent, ${ }^{260-264}$ among others. ${ }^{265}$ The clinical approval of Ebselen has also stimulated the synthesis of Ebselen derivatives. ${ }^{70,266-273}$

A brief historical account of the biological timeline of selenium is presented below (Table 8).

Table 8. Timeline of selenium in science

\begin{tabular}{|c|c|c|}
\hline Year & Important fact & $\begin{array}{l}\text { Cited by } \\
\text { reference }\end{array}$ \\
\hline 1295 & $\begin{array}{l}\text { Perhaps the first description of chronic selenosis in animals, but } \\
\text { not proved. }\end{array}$ & 274 \\
\hline 1560 & $\begin{array}{l}\text { Perhaps the first description of chronic selenosis in humans, but } \\
\text { not proved. }\end{array}$ & 274 \\
\hline 1817 & Discovery of selenium by Berzelius. & 1 \\
\hline 1836 & Synthesis of diethylselenide reported by Löwing. & 70 \\
\hline 1847 & Wöhler and Siemens synthetize selenomercaptans. & 122,123 \\
\hline 1860 & $\begin{array}{l}\text { Madison describes the poisoning of cavalry horse by plants, } \\
\text { which later were shown to have high selenium content. }\end{array}$ & 3 \\
\hline 1894 & $\begin{array}{l}\text { Hofmeister identifies dimethylselenide as the cause of garlic-like } \\
\text { odor in the breath. }\end{array}$ & 165 \\
\hline 1909 & $\begin{array}{l}\text { Jones demonstrates brick red precipitate in organs of animal } \\
\text { intoxicated with selenite. }\end{array}$ & 144 \\
\hline 1919 & Therapeutic use of colloidal selenium against cancer. & 181 \\
\hline 1924 & Lesser and Weiss synthesize Ebselen. & 128 \\
\hline 1934 & $\begin{array}{c}\text { Franke and collaborators demonstrate that grain containing } \\
\text { elevated levels of selenium was directly associated with regions } \\
\text { that presented alkali disease in cattle. }\end{array}$ & $203-206$ \\
\hline 1954 & $\begin{array}{l}\text { Selenite was shown to be essential for formate dehydrogenase } \\
\text { synthesis in bacteria. }\end{array}$ & 275 \\
\hline 1957 & $\begin{array}{l}\text { Selenium discovered as an integral part of factor } 3, \text { which } \\
\text { prevents liver degeneration caused by vitamin E deficiency. }\end{array}$ & 251 \\
\hline 1958 & $\begin{array}{c}\text { Organoselenium compounds prevented liver degeneration } \\
\text { caused by a vitamin E deficient diet. }\end{array}$ & 250 \\
\hline 1973 & Presence of selenium in mammalian glutathione peroxidase. & 131,132 \\
\hline
\end{tabular}


Table 8. Continued

\begin{tabular}{|c|c|c|}
\hline Year & Important fact & $\begin{array}{l}\text { Cited by } \\
\text { reference nos }\end{array}$ \\
\hline 1976 & $\begin{array}{l}\text { Occurrence of selenocysteine in catalytic site of glycine } \\
\text { reductase from bacteria. }\end{array}$ & 37 \\
\hline 1978 & $\begin{array}{c}\text { Occurrence of selenocysteine in catalytic site of glutathione } \\
\text { peroxidase from mammalian. }\end{array}$ & 4 \\
\hline 1986 & $\begin{array}{l}\begin{array}{l}\text { Discovery of UGA as the selenocysteine codon in bacteria and } \\
\text { eukaryotes. }\end{array}\end{array}$ & 276,277 \\
\hline 1989 & Discovery of selenocysteinyl tRNA. & 278 \\
\hline 1992 & Discovery of bacterial SECIS mRNA. & 279 \\
\hline 1998 & Clinical trials with Ebselen. & $125-127,129,130$ \\
\hline
\end{tabular}

\section{Concluding Remarks and Perspectives}

The biological interest in selenium has paralleled that of organoselenium compounds before and after the recognition that selenium has physiological roles in some forms of life. Nowadays, the great challenge of organoseleno synthetic chemists is to create molecular moieties capable of imitating the physiological chemistry of selenium (i.e., selenoproteins) without being toxic to the living cells. Optimistically, the new compounds will need to have selectivity and catalyze specific reactions. This will be an advance over contemporary organoselenium compounds that can imitate non-specifically the reactions catalyzed by different isoforms of selenoenzymes. Here it is also important to emphasize that the development of selenium-containing molecules that can selectively interact with specific thiol-containing proteins will also be of great therapeutic value. The development of molecules that could delivery selenium preferentially to specific tissues or groups of cells can also be important to the treatment of cancer and other pathologies. The tasks are hard, but the field is slowly moving forward. The bottlenecks here are: 1) the absence of in silico methods to predict the chemical, biochemical and toxicological behavior of new molecules; 2) the limitation of in vitro methods to study the toxicological and biochemical properties of a large number of molecules (i.e., the available methods have limited capacity of predicting either the toxicity or the beneficial effects of new organoselenium compounds and 3) the limited number of compounds that have been studied in some detail from the biological point of view. Thus, it seems more reasonable to select some promising classes of compounds and test them mechanistically than to test a vast number of molecules in complex biological systems empirically. The probability of finding a target for an organoselenium compound by chance is very small. The use of available in silico methods can increase the chance of successful discovery of drugs with real therapeutic potential. Consequently, the in depth study of existing in silico methodologies and their improvement will be decisive for the future of the field of organoselenium compounds.

\section{References}

1. Comasseto, J. V. J. Braz. Chem. Soc. 2010, 21, 2027-2031.

http://dx.doi.org/10.1590/S0103-50532010001100003

2. Arnér, E. S. Exp. Cell Res. 2010, 316, 1296-1303. 
http://dx.doi.org/10.1016/j.yexcr.2010.02.032

3. Moxon, A. L.; Morris R. Physiol. Rev. 1943, 23, 305-337.

4. Forstrom, J. W.; Zakowski, J. J.; Tappel, A. L. Biochemistry 1978, 17, 2639-2644.

http://dx.doi.org/10.1021/bi00606a028

5. Hatfield, D. L.; Tsuji, P. A.; Carlson, B. A.; Gladyshev, V. N. Trends Biochem. Sci. 2014, 39, 112-120. http://dx.doi.org/10.1016/j.tibs.2013.12.007

6. Lobanov, A. V.; Hatfield, D. L.; Gladyshev, V. N. Biochim. Biophys. Acta 2009, 1790, 1424-1428. http://dx.doi.org/10.1016/j.bbagen.2009.05.014

7. Wrobel, J. K.; Power, R.; Toborek, M. IUBMB Life 2016, 68, 97-105. http://dx.doi.org/10.1002/iub.1466

8. Cardoso, B. R.; Roberts, B.R.; Bush, A. I.; Hare, D. J. Metallomics 2015, 7, 1213-28. http://dx.doi.org/10.1039/C5MT00075K

9. Gladyshev, V. N.; Hatfield, D. L. J. Biomed. Sci. 1999, 6, 151-160.

http://dx.doi.org/10.1007/BF02255899

10. Gromer, S.; Eubel, J. K.; Lee, B. L.; Jacob, J. Cell. Mol. Life Sci. 2005, 62, 2414-2437.

http://dx.doi.org/10.1007/s00018-005-5143-y

11. Kryukov, G. V.; Castellano, S.; Novoselov, S. V.; Lobanov, A. V.; Zehtab, O.; Guigó, R.; Gladyshev, V. N. Science 2003, 300, 1439-1443.

http://dx.doi.org/10.1126/science.1083516

12. Alshaikh, B.; Schall, J. I.; Maqbool, A.; Mascarenhas, M.; Bennett, M.J.; Stallings, V.A. Nutr. Res. 2016, 36, 418-429.

http://dx.doi.org/10.1016/j.nutres.2015.12.014

13. Johansson, L.; Gafvelin, G.; Arnér, E. S. J. Biochim. Biophys. Acta 2005, 1726, 1-13.

http://dx.doi.org/10.1016/j.bbagen.2005.05.010

14. Hassan, W. S.; Oliveira C. S.; Noreen H. P.; Kamdem J. Nogueira C. W.; Rocha J. B. T. Curr. Org. Chem. 2016, 1, 218-231.

15. Poole, L. B. Free Radic. Biol. Med. 2015, 80, 148-157.

http://dx.doi.org/10.1016/i.freeradbiomed.2014.11.013

16. Devarie-Baez, N. O.; Silva Lopez, E. I.; Furdui, C. M. Free Radic. Res. 2016, 50, 172-194.

http://dx.doi.org/10.3109/10715762.2015.1090571

17. Boronat, S.; García-Santamarina, S.; Hidalgo, E. Free Radic. Res. 2015, 49, 494-510.

http://dx.doi.org/10.3109/10715762.2015.1009053

18. Roos, G.; Messens, J. Free Radic. Biol. Med. 2011, 51, 314-326.

http://dx.doi.org/10.1016/i.freeradbiomed.2011.04.031

19. Singh, A.; Ling, G.; Suhasini, A. N.; Zhang, P.; Yamamoto, M.; Navas-Acien, A.; Cosgrove, G.; Tuder, R. M.; Kensler, T. W.; Watson, W. H.; Biswal, S. Free Radic. Biol. Med. 2009, 46, 376-386.

http://dx.doi.org/10.1016/i.freeradbiomed.2008.10.026

20. Devarie-Baez, N. O.; Silva Lopez, E. I.; Furdui, C. M. Free Radic. Res. 2016, 50, 172-194.

http://dx.doi.org/10.3109/10715762.2015.1090571

21. Kalinina, E. V.; Chernov, N. N.; Novichkova, M. D. Biochem. (Moskva) 2014, 79, 1562-1583. http://dx.doi.org/10.1134/S0006297914130082

22. Radzishevsky, I.; Sason, H.; Wolosker, H. Curr. Opin. Clin. Nutr. Metab. Care 2013, 16, 72-75. http://dx.doi.org/10.1097/MCO.0b013e32835a3466 
23. Wolosker, H.; Panizzutti, R.; De Miranda, J. Neurochem. Int. 2002, 41, 327-332. http://dx.doi.org/10.1016/S0197-0186(02)00055-4

24. Wolosker, H.; Radzishevsky, I. Biochem. Soc. Trans. 2013, 41, 1546-1550. http://dx.doi.org/10.1042/BST20130220

25. Roman, M.; Jitaru, P.; Barbante, C. Metallomics 2014, 6, 25-54. http://dx.doi.org/10.1039/C3MT00185G

26. Labunskyy, V. M.; Hatfield, D. L.; Gladyshev, V. N. Physiol. Rev. 2014, 94, 739-777. http://dx.doi.org/10.1152/physrev.00039.2013

27. Lu, J.; Holmgren, A. J. Biol. Chem. 2009, 284, 717-721. http://dx.doi.org/10.1074/jbc.R800055200

28. Sarma, B. K.; Mugesh, G. Org. Biomol. Chem. 2008, 6, 965-974. http://dx.doi.org/10.1039/b716239a

29. Achilli, C.; Ciana, A.; Minetti, G. Biofactors 2015, 41, 135-152.

http://dx.doi.org/10.1002/biof.1214

30. Hatfield, D. L.; Gladyshev, V. N. Mol. Cell. Biol. 2002, 22, 3565-3576. http://dx.doi.org/10.1128/MCB.22.11.3565-3576.2002

31. Böck, A.; Forchhammer, K.; Heider, J.; Leinfelder, W.; Sawers, G.; Veprek, B.; Zinoni, F. Mol. Microbiol. 1991, 5, 515-520. http://dx.doi.org/10.1111/j.1365-2958.1991.tb00722.x

32. Low, S. C.; Berry, M. J. Trends Biochem. Sci. 1996, 21, 203-208. http://dx.doi.org/10.1016/S0968-0004(96)80016-8

33. Stadtman, T. C. Annu. Rev. Biochem. 1996, 65, 83-100. http://dx.doi.org/10.1146/annurev.bi.65.070196.000503

34. Goto, K.; Sonoda, D.; Shimada, K.; Sase, S.; Kawashima, T. Angew. Chem. Int. Ed. 2010, 49, 545-547. http://dx.doi.org/10.1002/anie.200905796

35. Berry, M. J.; Banu, L.; Larsen, P. R. Nature 1991, 349, 438-440. http://dx.doi.org/10.1038/349438a0

36. Behne, D.; Kyriakopoulos, A.; Meinhold, H.; Köhrle, J. Biochem. Biophys. Res. Commun. 1990, 173, 11431149.

http://dx.doi.org/10.1016/S0006-291X(05)80905-2

37. Cone, J. E.; Martin Del Rio, R.; Davis, J. N.; Stadtman, T. C. Proc. Natl. Acad. Sci. U. S. A. 1976, 73, 26592663. http://dx.doi.org/10.1073/pnas.73.8.2659

38. Kim, H. Y.; Fomenko, D. E.; Yoon, Y. E.; Gladyshev, V. N. Biochemistry 2006, 45, 13697-13704. http://dx.doi.org/10.1021/bi0611614

39. Kozak, M. Microbiol. Rev. 1983, 47-455.

40. Jacob, C.; Giles, G. I.; Giles, N. M.; Sies, H. Angew. Chem. Int. 2003, 42, 4742-4758. http://dx.doi.org/10.1002/anie.200300573

41. Fomenko, D. E.; Gladyshev, V. N. Antioxid. Redox. Signal. 2012, 16, 193-201. http://dx.doi.org/10.1089/ars.2011.3980

42. Fomenko, D. E.; Marino, S. M.; Gladyshev, V. N. Mol. Cells 2008, 26, 228-235.

43. Fomenko, D. E.; Xing, W.; Adair, B. M.; Thomas, D. J.; Gladyshev, V. N. Science 2007, 315, 387-389. http://dx.doi.org/10.1126/science.1133114 
44. Miseta, A.; Csutora, P. Mol. Biol. Evol. 2000, 1232-1239.

http://dx.doi.org/10.1093/oxfordjournals.molbev.a026406

45. Araie, H.; Shiraiwa, Y. Molecules 2009, 14, 4880-4891.

http://dx.doi.org/10.3390/molecules14124880

46. Huber, R. E.; Criddle, R. S. Arch. Biochem. Biophys. 1967, 122, 164-173.

http://dx.doi.org/10.1016/0003-9861(67)90136-1

47. Dickson, R. C.; Tappel, A. L. Arch. Biochem. Biophys. 1969, 130, 547-550.

http://dx.doi.org/10.1016/0003-9861(69)90068-X

48. Painter, E. P. Chem. Rev. 1941, 28, 179-213.

http://dx.doi.org/10.1021/cr60090a001

49. Behne, D.; Hilmert, H.; Scheid, S.; Gessner, H.; Elger, W. Biochim. Biophys. Acta 1988, 966, 12-21. http://dx.doi.org/10.1016/0304-4165(88)90123-7

50. Schomburg, L.; Schweizer, U. Biochim. Biophys. Acta 2009, 1790, 1453-1462.

51. Burk, R. F.; Hill, K. E. Annu. Rev. Nutr. 2015, 35, 109-134.

http://dx.doi.org/10.1146/annurev-nutr-071714-034250

52. Chen, J.; Berry, M. J. J. Neurochem. 2003, 86, 1-12.

http://dx.doi.org/10.1046/j.1471-4159.2003.01854.x

53. Solovyev, N. D. J. Inorg. Biochem. 2015, 153, 1-12.

http://dx.doi.org/10.1016/j.jinorgbio.2015.09.003

54. Pavlidou, E.; Salpietro, V.; Phadke, R.; Hargreaves, I. P.; Batten, L.; McElreavy, K.; Pitt, M.; Mankad, K.; Wilson, C.; Cutrupi, M. C.; Ruggieri, M.; McCormick, D.; Saggar, A.; Kinali, M. Eur. J. Paediatr. Neurol. 2016, 20, 483-488.

http://dx.doi.org/10.1016/i.ejpn.2015.12.016

55. Boukhzar, L.; Hamieh, A.; Cartier, D.; Tanguy, Y.; Alsharif, I.; Castex, M.; Arabo, A.; Hajji, S. E.; Bonnet, J. J.; Errami, M.; Falluel-Morel, A.; Chagraoui, A.; Lihrmann, I.; Anouar, Y. Antioxid Redox Signal. 2016, 24, 557574.

http://dx.doi.org/10.1089/ars.2015.6478

56. Dominiak, A.; Wilkaniec, A.; Wroczyński, P.; Adamczyk, A. Curr. Neuropharmacol. 2016, 14, $282-299$. http://dx.doi.org/10.2174/1570159X14666151223100011

57. Seeher, S.; Carlson, B. A.; Miniard, A. C.; Wirth, E. K.; Mahdi, Y.; Hatfield, D. L.; Driscoll, D. M.; Schweizer, U. Biochem. J. 2014, 462, 67-75.

http://dx.doi.org/10.1042/BJ20140423

58. Byrns, C. N.; Pitts, M. W.; Gilman, C. A.; Hashimoto, A. C.; Berry, M. J. J. Biol. Chem. 2014, 289, 96629674.

http://dx.doi.org/10.1074/jbc.M113.540682

59. Pillai, R.; Uyehara-Lock, J. H.; Bellinger, F. P. IUBMB Life 2014, 66, 229-239.

http://dx.doi.org/10.1002/iub.1262

60. Pitts, M. W.; Byrns, C. N.; Ogawa-Wong, A. N.; Kremer, P.; Berry, M. J. Biol. Trace Elem. Res. 2014, 161, 231-245.

http://dx.doi.org/10.1007/s12011-014-0060-2

61. Schweizer, U.; Dehina, N.; Schomburg, L. Curr. Opin. Pediatr. 2011, 23, 429-435.

http://dx.doi.org/10.1097/MOP.0b013e32834877da

62. Reich, H. J.; Hondal, R. J. ACS Chem. Biol. 2016, 11, 821-841. 
http://dx.doi.org/10.1021/acschembio.6b00031

63. Lehninger, A. L. Biochemistry: The Molecular Basis of Cell Structure and Function, 2nd Edition; Worth Pub; $2^{\text {nd }}$ edition 1, 1978

64. Li, F.; Lutz, P.B.; Pepelyayeva, Y.; Arnér, E. S. J.; Bayse, C. A.; Rozovsky, S. Proc. Natl. Acad. Sci. U. S. A. 2014, 111, 6976-6981.

http://dx.doi.org/10.1073/pnas.1319022111

65. Piętka-Ottlik, M.; Potaczek, P.; Piasecki, E.; Mlochowski, J. Molecules 2010, 15, 8214-8228. http://dx.doi.org/10.3390/molecules15118214

66. Billack, B.; Piętka-Ottlik, M.; Santoro, M.; Nicholson, S.; Młochowski, J.; Lau-Cam, C. J. Enzyme Inhib. Med. Chem. 2010, 25, 312-317.

http://dx.doi.org/10.3109/14756360903179419

67. Piętka-Ottlik, M.; Wójtowicz-Młochowska, H.; Kołodziejczyk, K.; Piasecki, E.; Młochowski, J. Chem. Pharm. Bull. 2008, 56, 1423-1427.

http://dx.doi.org/10.1248/cpb.56.1423

68. Wójtowicz, H.; Kloc, K.; Maliszewska, I.; Młochowski, J.; Piętka, M.; Piasecki, E., Farmaco 2004, 59, 863868.

http://dx.doi.org/10.1016/j.farmac.2004.07.003

69. Palus, J.; Dabrowska, E.; Pietka-Ottlik, M.; Piasecki, E.; Młochowski, J. Pol. J. Chem. 2008, 82, 1015-1022.

70. Młochowski, J.; Kloc, K.; Lisiak, R.; Potaczek, P.; Wójtowicz, H. Arkivoc. 2007, (vi) 14-46.

71. Palus, J.; Chojnacka, M.; Piasecki, E.; Zboińska, E.; Młochowski, J. Pol. J. Chem. 2004, 78, 2117-2126.

72. Bien, M.; Blaszczyk, B.; Kalinowska, K.; Mlochowski, J.; Inglot, A. D. Arch. Immunol. Ther. Exp. 1999, 47, 185-193.

73. Młochowski, J.; Gryglewski, R. J.; Inglot, A. D.; Jakubowski, A.; Juchniewicz, L.; Kloc, K. Liebigs Ann. 1996, 1751-1755.

http://dx.doi.org/10.1002/ilac.199619961108

74. Inglot, A. D.; Młochowski, J.; Zielińska-Jenczylik, J.; Piasecki, E.; Ledwoń, T. K.; Kloc, K. Arch. Immunol. Ther. Exp. 1996, 44, 67-75.

75. Blaszczyk, B.; Inglot, A. D.; Kowalczyk-Bronisz, S. H.; Szymaniec, S.; Mlochowski, J. Arch. Immunol. Ther. Exp. 1995, 43, 305-311.

76. Blaszczyk, B.; Inglot, A. D.; Toivanen, P.; Mlochowski, J.; Szymaniec, S. Arch. Immunol. Ther. Exp. 1995, 43, 299-303.

77. Hatchett, R. J.; Gryglewski, R. J.; Mlochowski, J.; Zembowicz, A.; Radziszewski, W. J. Physiol. Pharmacol. 1994, 45, 55-67.

78. Piasecki, E.; Inglot, A.D.; Zielinska-Jenczylik, J.; Mlochowski, J.; Syper, L. Arch. Immunol. Ther. Exp. 1992, 40, 229-234.

79. Mlochowski, J.; Kloc, K.; Syper, L.; Inglot, A. D. Phosphorus Sulfur Silicon Relat. Elem. 1991, 59, $267-270$. http://dx.doi.org/10.1080/10426509108045739

80. Inglot, A. D.; Zielińska-Jenczylik, J.; Piasecki, E.; Syper, L.; Młochowski, J. Experientia 1990, 46, 308-311.

81. http://dx.doi.org/10.1007/BF01951774

82. Arai, K.; Iwaoka, M. Curr. Org. Chem. 2016, 20, 155-165.

http://dx.doi.org/10.2174/1385272819666150724233306

83. Palomba, M.; Bagnoli, L.; Marini, F.; Santi, C.; Sancineto, L. Phosphorus Sulfur Silicon Relat. Elem. 2016, 191, 235-244. 
http://dx.doi.org/10.1080/10426507.2015.1067212

84. Sancineto, L.; Palomba, M.; Bagnoli, L.; Marini, F.; Santi, C. Curr. Org. Chem. 2016, 20, 122-135. http://dx.doi.org/10.2174/1385272819666150724233204

85. Santoro, S.; Azeredo, J. B.; Nascimento, V.; Sancineto, L.; Braga, A. L.; Santi, C. RSC Adv. 2014, 4, 3152131535.

http://dx.doi.org/10.1039/C4RA04493B

86. Rafique, J.; Canto, R. F. S.; Saba, S.; Barbosa, F. A. R.; Braga, A. L. Curr. Org. Chem. 2016, 20, 166-188. http://dx.doi.org/10.2174/1385272819666150810222057

87. Garud, D. R.; Koketsu, M.; Ishihara, H. Molecules 2007, 12, 504-535. http://dx.doi.org/10.3390/12030504

88. Santi, C.; Tidei, C.; Scalera, C.; Piroddi, M.; Galli, F. Curr. Chem. Biol. 2013, 7, 25-36. http://dx.doi.org/10.2174/2212796811307010003

89. Elsherbini, M.; Hamama, W. S.; Zoorob, H. H. Coordin. Chem. Rev. 2016, 312, 149-177. http://dx.doi.org/10.1016/i.ccr.2016.01.003

90. Sashida, H. Yakugaku Zasshi. 2016, 136, 841-871. http://dx.doi.org/10.1248/yakushi.15-00208

91. Młochowski, J.; Wójtowicz-Młochowska, H. Molecules 2015, 20, 10205-10243. http://dx.doi.org/10.3390/molecules200610205

92. Kedarnath, G.; Jain, V. K. Coordin. Chem. Rev. 2013, 257, 1409-1435. http://dx.doi.org/10.1016/i.ccr.2013.01.003

93. Kumar, A.; Rao, G. K.; Saleem, F.; Singh, A. K. Dalton Trans. 2012, 41, 11949-11977. http://dx.doi.org/10.1039/c2dt31198d

94. Rhoden, C. R. B.; Zeni, G. Org. Biomol. Chem. 2011, 9, 1301-1313. http://dx.doi.org/10.1039/c0ob00557f

95. Alberto, E. E.; Nascimento, V. D.; Braga, A. L. J. Braz. Chem. Soc. 2010, 21, 2032-2041. http://dx.doi.org/10.1590/S0103-50532010001100004

96. Perin, G.; Lenardão, E. J.; Jacob, R. G. Panatieri, R. B. Chem. Rev. 2009, 109, 1177-1301.

97. Elsherbini, M.; Hamama, W. S.; Zoorob, H. H. Coordin. Chem. Rev. 2016, 312, 149-177. http://dx.doi.org/10.1016/j.ccr.2016.01.003

98. Iwaoka, M.; Arai, K. Curr. Chem. Biol. 2013, 7, 2-24. http://dx.doi.org/10.2174/2212796811307010002

99. Wirth, T. Angew. Chem. Int. Ed. 2000, 39, 3741-3749.

100. Freudendahl, D. M.; Shahzad, S. A.; Wirth, T. Eur. J. Org. Chem. 2009, 11, 1649-1664. http://dx.doi.org/10.1002/ejoc.200801171

101. Mugesh, G.; Du Mont, W. W.; Sies, H. Chem. Rev. 2001, 101, 2125-2179. http://dx.doi.org/10.1021/cr000426w

102. Nogueira, C. W.; Zeni, G.; Rocha, J. B. T. Chem. Rev. 2004, 104, 6255-6285. http://dx.doi.org/10.1021/cr0406559

103. Mugesh, G.; Singh, H. B. Chem. Soc. Rev. 2000, 29, 347-357. http://dx.doi.org/10.1039/a908114c

104. Bhabak, K. P.; Mugesh, G. A. Chem. Res. 2010, 43, 1408-1419. http://dx.doi.org/10.1021/ar100059g

105. Nogueira, C. W.; Rocha, J. B. T. Arch. Toxicol. 2011, 85, 1313-1359. 
http://dx.doi.org/10.1007/s00204-011-0720-3

106. May, S. W. Top. Med. Chem. 2016, 17, 87-118.

http://dx.doi.org/10.1007/7355 2015 86

107. Tapiero, H. ; Townsend, D. M. ; Tew, K. D. Biomed. Pharmacother. 2003, 57, 134-144. http://dx.doi.org/10.1016/S0753-3322(03)00035-0

108. Azad, G. K.; Tomar, R. S. Mol. Biol. Rep. 2014, 41, 4865-4879.

http://dx.doi.org/10.1007/s11033-014-3417-x

109. Nogueira, C. W.; Rocha, J. B. T. J. Brazil. Chem. Soc. 2010, 21, 2055-2071. http://dx.doi.org/10.1590/S0103-50532010001100006

110. Sanmartín, C.; Plano, D.; Sharma, A. K.; Palop, J. A. Int. J. Mol. Sci. 2012, 13, 9649-9672. http://dx.doi.org/10.3390/ijms13089649

111. López, Ó.; Merino-Montiel, P.; Fernández-Bolaños, J. G. Food Nutr. Components Focus. 2015, 40-64.

112. Orian, L; Toppo, S. Free Rad. Biol. Med. 2014 , 66, 65-74. http://dx.doi.org/10.1016/i.freeradbiomed.2013.03.006

113. Lee, J. I.; Nian, H.; Cooper, A. J.; Sinha, R.; Dai, J.; Bisson, W. H.; Dashwood, R. H.; Pinto, J. T. Cancer Prev. Res. 2009, 2, 683-693. http://dx.doi.org/10.1158/1940-6207.CAPR-09-0047

114. Rizvi, M. A.; Guru, S.; Naqvi, T.; Kumar, M.; Kumbhar, N.; Akhoon, S.; Banday, S.; Singh, S. K.; Bhushan, S.; Peerzada, G. M.; Shah, B. A. Bioorg. Med. Chem. Lett. 2014, 24, 3440-3446. http://dx.doi.org/10.1016/j.bmcl.2014.05.075

115. Shimada, T.; Murayama, N.; Tanaka, K.; Takenaka, S.; Guengerich, F. P.; Yamazaki, H.; Komori, M. Chem. Res. Toxicol. 2011, 24, 1327-1337. http://dx.doi.org/10.1021/tx200218u

116. Rescifina, A.; Zagni, C.; Varrica M. G.; Pistarà V.; Corsaro A. Eur. J. Med. Chem. 2014, 74, 95-115. http://dx.doi.org/10.1016/j.ejmech.2013.11.029

117. Canto, R. F.; Barbosa, F. A.; Nascimento V.; de Oliveira, A. S.; Brighente, I. M.; Braga, A. L. Org. Biomol. Chem. 2014, 12, 3470-3477. http://dx.doi.org/10.1039/c4ob00598h

118. Wolters, L.; Orian, L. Curr. Org. Chem. 2016, 20, 189-197. http://dx.doi.org/10.2174/1385272819666150724233655

119. Zaccaria, F.; Wolters, L. P.; Fonseca Guerra, C.; Orian, L. J. Comput. Chem. 2016, 37, 1672-1680. http://dx.doi.org/10.1002/jcc.24383

120. Martinez-Ramos, F.; Fonseca-Sabater, Y.; Soriano-Ursúa, M. A.; Torres, E.; Rosales-Hernández, M. C.; Trujillo-Ferrara, J. G.; Tolentino-Lopez, L. E.; Ian, I. F.; Correa-Basurto, J. Protein Pept. Lett. 2013, 20, 70514.

http://dx.doi.org/10.2174/0929866511320060009

121. Shaaban, S.; Negm, A.; Ashmawy, A. M.; Ahmed, D. M.; Wessjohann, L. A. Eur. J. Med. Chem. 2016, 122, 55-71.

http://dx.doi.org/10.1016/j.ejmech.2016.06.005

122. Smith, S. M.; Min, J.; Ganesh, T.; Diebold, B.; Kawahara, T.; Zhu, Y.; McCoy, J.; Sun, A.; Snyder, J. P.; Fu, H.; Du, Y. Chem. Biol. 2012, 19,752-763. http://dx.doi.org/10.1016/i.chembiol.2012.04.015

123. Fredga, A. Ann. N. Y. Acad. Sci. 1972, 192, 1-9. 
http://dx.doi.org/10.1111/j.1749-6632.1972.tb52571.x

124. Shaw Jr, E. H.; Reid, E. E. J. Am. Chem. Soc. 1926, 48, 520-528.

http://dx.doi.org/10.1021/ja01413a033

125. The organic compounds of tellurium and selenium belonging to the alcohol series, Dean, J. 1855.

126. Saito, I.; Asano, T.; Sano, K.; Takakura, K.; Abe, H.; Yoshimoto, T.; Kikuchi, H., Ishibashi, S. Neurosurgery 1998, 42, 269-278.

http://dx.doi.org/10.1097/00006123-199802000-00038

127. Yamaguchi, T.; Sano, K.; Takakura, K.; Saito, I.; Shinohara, Y.; Asano, T.; Yasuhara, H. Stroke 1998, 29, $12-$ 17.

http://dx.doi.org/10.1161/01.STR.29.1.12

128. Ogawa, A.; Yoshimoto, T.; Kikuchi, H.; Sano, K.; Saito, I.; Yamaguchi, T.; Yasuhara, H. Cerebrovasc. Dis. 1999, 9, 112-118.

http://dx.doi.org/10.1159/000015908

129. Lesser, R.; Weiss, R. Ber. Dtsch. Chem. Ges. 1924, 57, 1077-1082.

http://dx.doi.org/10.1002/cber.19240570703

130. Parnham, M. J.; Sies, H. Biochem. Pharmacol. 2013, 86, 1248-1253.

http://dx.doi.org/10.1016/j.bcp.2013.08.028

131. Noguchi, N. Arch. Biochem. Biophys. 2016, 595, 109-112.

http://dx.doi.org/10.1016/j.abb.2015.10.024

132. Flohe, L.; Günzler, W. A.; Schock, H. H. FEBS Lett. 1973, 32, 132-134.

http://dx.doi.org/10.1016/0014-5793(73)80755-0

133. Rotruck, J. T.; Pope, A. L.; Ganther, H. E.; Swanson, A. B.; Hafeman, D. G.; Hoekstra, W. Science. 1973, 179, 588-590.

http://dx.doi.org/10.1126/science.179.4073.588

134. Frost D. V.; Olson O. E. CRC Crit. Rev. Tox. 1972, 1, 467-514.

http://dx.doi.org/10.3109/10408447209103467

135. Morgenstern, R.; Cotgreave, I. A.; Engman, L. Chem. Biol. Interact. 1992, 84, 77-84.

http://dx.doi.org/10.1016/0009-2797(92)90122-2

136. Wilson, S. R.; Zucker, P. A.; Huang, R. R. C.; Spector, A. J. Am. Chem. Soc. 1989, 111, 5936-5939. http://dx.doi.org/10.1021/ja00197a065

137. Haenen, G. R.; De Rooij, B. M.; Vermeulen, N. P.; Bast, A. A. L. T. Mol. Pharmacol. 1990, 37, $412-422$.

138. Back, T. G.; Moussa, Z. J. Am. Chem. Soc. 2003, 125, 13455-13460.

http://dx.doi.org/10.1021/ja0357588

139. Zhao, R.; Holmgren, A. J. Biol. Chem. 2002, 277, 39456-39462.

http://dx.doi.org/10.1074/jbc.M206452200

140. Zhao, R.; Masayasu, H.; Holmgren, A. Proc. Natl. Acad. Sci. 2002, 99, 8579-8584.

http://dx.doi.org/10.1073/pnas.122061399

141. de Freitas, A. S.; Prestes, A. S.; Wagner, C., Sudati, J. H.; Alves, D.; Porciúncula, L. O.; Kade, I. J.; Rocha, J.

B. T. Molecules. 2010, 15, 7699-7714.

http://dx.doi.org/10.3390/molecules15117699

142. Kade, I. J.; Balogun, B. D.; Rocha, J. B. T. Chem. Biol. Interact. 2013, 206, 27-36.

http://dx.doi.org/10.1016/i.cbi.2013.07.014

143. Rocha, J. B. T.; Saraiva, R. A.; Garcia, S. C.; Gravina, F. S.; Nogueira, C. W. Toxicol. Res. 2012, 1, 85-102. 
http://dx.doi.org/10.1039/c2tx20014g

144. Singh, N.; Halliday, A. C.; Thomas, J. M.; Kuznetsova, O.; Baldwin, R.; Woon, E. C. Y.; Aley, P. K.; Antoniadou, I.; Sharp, T.; Vasudevan, S. R.; Churchill, G. C. Nat. Commun. 2013, 4, 2320.

145. Posser, T.; Kaster, M. P.; Baraúna, S. C., Rocha, J. B.T.; Rodrigues, A. L. S.; Leal, R. B. Eur. J. Pharmacol. 2009, 602, 85-91.

http://dx.doi.org/10.1016/i.ejphar.2008.10.055

146. Kobayashi, A.; Ohta, T.; Yamamoto, M. Method. Enzymol. 2004, 378, 273-286.

http://dx.doi.org/10.1016/S0076-6879(04)78021-0

147. Kansanen, E.; Kuosmanen, S. M.; Leinonen, H.; Levonenn, A. L. Redox Biol. 2013, 1, 45-49. http://dx.doi.org/10.1016/j.redox.2012.10.001

148. Sobočanec, S.; Filić, V.; Matovina, M.; Majhen, D.; Šafranko, T. M.; Hadžija, M. P.; Krsnik, Z.; Kurilj, A. G.; Šarić, A.; Abramić, M.; Balog, T. Redox Biol. 2016, 8, 149-159.

http://dx.doi.org/10.1016/j.redox.2016.01.003

149. Abolaji, A. O.; Kamdem, J. P.; Lugokenski, T. H.; Farombi, E. O.; Souza, D. O.; da Silva Loreto, T. L.; Rocha, J. B. T. Redox Biol. 2015, 5, 328-339.

150. http://dx.doi.org/10.1016/j.redox.2015.06.001

151. Cheng, T.; Wang, W.; Li, Q.; Han, X.; Xing, J.; Qi, C.; Lan, X.; Wan, J.; Potts, A.; Guan, F.; Wang, J. Free Radic. Biol. Med. 2016, 92, 15-28.

http://dx.doi.org/10.1016/j.freeradbiomed.2015.12.027

152. Zhang, G.; Nitteranon, V.; Guo, S.; Qiu, P.; Wu, X.; Li, F.; Xiao, H.; Hu, Q.; Parkin, K. L. Chem. Res. Toxicol. 2013, 26, 456-464.

http://dx.doi.org/10.1021/tx300515j

153. Sakurai, T.; Kanayama, M.; Shibata, T.; Itoh, K.; Kobayashi, A. Chem. Res. Toxicol. 2006, 19, 1196-1204. http://dx.doi.org/10.1021/tx0601105

154. Tamasi, V.; Jeffries, J. M.; Arteel, G. E.; Falkner, K. C. Arch. Biochem. Bioph. 2004, 431, 161-168. http://dx.doi.org/10.1016/j.abb.2004.07.030

155. Wood-Allum, C. A.; Barber, S. C.; Kirby, J.; Heath, P.; Holden, H.; Mead, R.; Higginbottom, A.; Allen, S.; Beaujeux, T.; Alexson, S. E.; Ince, P. G.; Shaw, P. J. Brain 2006, 129, 1693-1709.

http://dx.doi.org/10.1093/brain/awl118

156. De Bem, A. F.; Fiuza, B.; Calcerrada, P.; Brito, P. M.; Peluffo, G.; Dinis, T. C. P.; Trujillo, M.; Rocha, J. B. T.; Radi, R.; Almeida, L. M. Nitric Oxide Biol. Chem. 2013, 31, 20-30.

157. Fiuza, B.; Subelzú, N.; Calcerrada, P.; Straliotto, M. R.; Piacenza, L.; Cassina, A.; Rocha, J. B.; Radi, R.; De Bem, A. F.; Peluffo, G. Free Radic. Res. 2015, 49, 122-132.

http://dx.doi.org/10.3109/10715762.2014.983096

158. Glaser, V.; Moritz, B.; Schmitz, A.; Dafré, A. L.; Nazari, E. M.; Müller, Y. M. R.; Feksa, L.; Straliottoa, M. R.; De Bem, A. F.; Farina, M.; Rocha, J. B. T. Chem. Biol. Interac. 2013, 206, 18-26.

http://dx.doi.org/10.1016/i.cbi.2013.08.002

159. Dias, G. R. M.; Golombieski, R. M.; Portella, R. L.; Amaral, G. P.; Soares, F. A.; Rocha, J. B. T.; Nogueira, C. W.; Barbosa, N. B. Neuroendocrinology 2014, 100, 45-59.

http://dx.doi.org/10.1159/000365515

160. Bruère, M. A. J. Anat. Physiol. 1891, 26, 62-75.

161. Jones, C. O. Biochem J. 1909, 4, 405-419.

http://dx.doi.org/10.1042/bj0040405 
162. Gmelin, C. G. Tübingen : H. Laupp'sche Buchhandlung 1824, 4, 1792-1860.

163. Levine, V. E. J. Bacteriol. 1925, 10, 217-262.

164. Blake, J. Am. J. Med. Sci. 1848, 29, 63-75.

165. Crookes, W. Q. J. Chem. Soc. London. 1852, 4, 12-20. http://dx.doi.org/10.1039/QJ8520400012

166. Challenger, F. Chem. Rev. 1945, 36, 315-361. http://dx.doi.org/10.1021/cr60115a003

167. McConnell, K. P.; Portman, O. W. J. Biol. Chem. 1952, 195, 277-282.

168. Daniels, L. A. Biol. Trace Elem. Res. 1996, 54, 185-199. http://dx.doi.org/10.1007/BF02784430

169. Hsieh, H. S.; Ganther, H. E. Biochemistry 1975, 14, 1632-1636. http://dx.doi.org/10.1021/bi00679a014

170. Hsieh, H. S.; Ganther, H. E.; Biochem. Biophys. Acta 1977, 497, 205-217. http://dx.doi.org/10.1016/0304-4165(77)90153-2

171. Tsen C. C.; Tappel, A. L. J. Biol. Chem. 1958, 233, 1230-1232.

172. Nonavinakere, V. K.; Potmis, R. A.; Rasekh, H. R.; Bell, R. R.; Early, J. L. Toxicol. Lett. 1993, 66, $273-279$. http://dx.doi.org/10.1016/0378-4274(93)90008-L

173. Early, J. L.; Schnell, R. C. Toxicol. Lett. 1982, 11, 253-257. http://dx.doi.org/10.1016/0378-4274(82)90158-8

174. Ganther H. E. Biochemistry 1968, 7, 2898-2905. http://dx.doi.org/10.1021/bi00848a029

175. Kim, T. S.; Jeong, D. W.; Byung, Y. Y.; Ick; Y. K. Biochem. Biophys. Res. Commun. 2002, 294, 1130-1137. http://dx.doi.org/10.1016/S0006-291X(02)00612-5

176. Stewart, M. S.; Spallholz, J. E.; Neldner, K. H.; Pence, B. C. Free Radic. Biol. Med. 1999, 26, $42-48$. http://dx.doi.org/10.1016/S0891-5849(98)00147-6

177. Kim, T. S.; Yun, B. Y.; Kim, I. Y. Biochem. Pharmacol. 2003, 66, 2301-2311. http://dx.doi.org/10.1016/j.bcp.2003.08.021

178. Lee, K. H.; Jeong, D. Mol. Med. Rep. 2012, 5, 299-304.

179. Nilsonne, G.; Sun, X.; Nyström, C.; Rundlöf, A. K.; Fernandes, A. P.; Björnstedt, M.; Dobra, K. Free Rad. Biol. Med. 2006, 41, 874-885 http://dx.doi.org/10.1016/j.freeradbiomed.2006.04.031

180. Jacques-Silva, M. C.; Nogueira, C. W.; Broch, L. C.; Flores, E. M.; Rocha, J. B. T. Pharmacol. Toxicol. 2001, $88,119-125$.

http://dx.doi.org/10.1034/i.1600-0773.2001.d01-92.x

181. Barbosa, N. B. V.; Rocha, J. B. T.; Zeni, G.; Emanuelli, T.; Beque, M. M.; Braga, A. L. Toxicol. Appl. Pharm. 1998, 149, 243-253.

http://dx.doi.org/10.1006/taap.1998.8373

182. Barron, E. G.; Kalnitsky, G. Biochem. J. 1947, 41, 346-351.

http://dx.doi.org/10.1042/bj0410346

183. Watson-Williams. E. Br. Med. J. 1919, 11, 463-469.

184. Norbury, L. E. Proc. R. Soc. Med. 1923, 16, 67.

185. Hernaman-Johnson F. Proc. R. Soc. Med. 1935, 28, 1182.

186. Patterson, B. H.; Levander, O. A. Cancer Epidemiol. Biomarkers Prev. 1997, 6, 63-69. 
187. Ip, C. J. Nutr. 1998, 128, 1845-1854.

188. Weekley, C. M.; Harris, H. H. Chem. Soc. Rev. 2013, 42, 8870-8894. http://dx.doi.org/10.1039/c3cs60272a

189. Misra, S.; Boylan, M.; Selvam, A.; Spallholz, J. E.; Björnstedt, M. Nutrients 2015, 7, 3536-3556. http://dx.doi.org/10.3390/nu7053536

190. Kieliszek, M.; Błazejak, S. Molecules 2016, 21, 609. http://dx.doi.org/10.3390/molecules21050609

191. Lü, J.; Zhang, J.; Jiang, C.; Deng, Y.; Özten, N.; Bosland, M. C. Nutr. Cancer 2016, 68, 1-17. http://dx.doi.org/10.1080/01635581.2016.1105267

192. Lippman, S. M.; Klein, E. A.; Goodman, P. J.; Lucia, M. S.; Thompson, I. M.; Ford, L. G.; Parnes, H. L.; Minasian, L. M.; Gaziano, J. M.; Hartline, J. A; Parsons, J. K. JAMA. 2009, 301, 39-51. http://dx.doi.org/10.1001/jama.2008.864

193. Klein, E. A.; Thompson, I. M.; Tangen, C. M.; Crowley, J. J.; Lucia, M. S.; Goodman, P. J.; Minasian, L. M.; Ford, L. G.; Parnes, H. L.; Gaziano, J. M.; Karp, D. D. JAMA. 2011, 306, 1549-1556.

http://dx.doi.org/10.1001/jama.2011.1437

194. Cai, X.; Wang, C.; Yu, W.; Fan, W.; Wang, S.; Shen, N.; Wu, P.; Li, X.; Wang, F. Sci. Rep. 2016, 6, 19213. http://dx.doi.org/10.1038/srep19213

195. Maasland, D. H. E.; Schouten, L. J.; Kremer, B.; Van Den Brandt, P. A. Eur. J. Cancer 2016, 60, 83-92. http://dx.doi.org/10.1016/j.ejca.2016.03.003

196. Lippman, S. M.; Goodman, P. J.; Klein, E. A.; Parnes, H. L.; Thompson, I. M.; Kristal, A. R.; Santella, R. M.; Probstfield, J.L.; Moinpour, C. M.; Albanes, D.; Taylor, P. R. J. Natl. Cancer Inst. 2005, 97, 94-102. http://dx.doi.org/10.1093/jnci/dji009

197. Duffield-Lillico, A. J.; Reid, M. E.; Turnbull, B. W.; Combs, G. F.; Slate, E. H.; Fischbach, L. A.; Marshall, J. R.; Clark, L. C. Cancer Epidemiol. Biomarkers Prev. 2002, 11, 630-639.

198. Larsen, E. H.; Hansen, M.; Paulin, H.; Moesgaard, S.; Reid, M.; Rayman, M. J. AOAC Int. 2004, 87, $225-232$.

199. Vinceti, M. Neurotoxicology 2013, 38, 25-32. http://dx.doi.org/10.1016/i.neuro.2013.05.016

200. Vinceti, M.; Rothman, K. J.; Bergomi, M.; Borciani, N.; Serra, L.; Vivoli, G. 1998. Cancer Epidemiol. Biomarkers Prev. 1998, 7, 853-856.

201. Vinceti, M.; Ballotari, P.; Steinmaus, C.; Malagoli, C.; Luberto, F.; Malavolti, M.; Rossi, P. G. Environ. Res. 2016, 150, 348-356.

http://dx.doi.org/10.1016/i.envres.2016.06.009

202. Stranges, S.; Sieri, S.; Vinceti, M.; Grioni, S.; Guallar, E.; Laclaustra, M.; Muti, P.; Berrino, F.; Krogh, V. BMC Public Health 2010, 10, 564.

http://dx.doi.org/10.1186/1471-2458-10-564

203. Bleys, J.; Navas-Acien A.; Guallar E. Diabetes Care. 2007, 30, 829-834. http://dx.doi.org/10.2337/dc06-1726

204. Park, K.; Rimm, E. B.; Siscovick, D. S.; Spiegelman, D.; Manson, J. E.; Morris, J. S.; Hu, F. B.; Mozaffarian, D. Diabetes Care. 2012, 35, 1544-1551. http://dx.doi.org/10.2337/dc11-2136

205. Oldfield, J. E. Anim. Sci. Online Supplement 2002, 1-4.

206. Smith, M. I.; Franke, K. W.; Westfall, B. B. Public Health Rep. 1936, 51, 1496-1505. http://dx.doi.org/10.2307/4581989 
207. Olson, O. E. Int. J. Toxicol. 1986, 5, 45-70. http://dx.doi.org/10.3109/10915818609140736

208. Koller, L. D.; Exon, J. H. Can. J. Vet. Res. 1986, 50, 297-306.

209. Franke, K. W. J. Nutr. 1934, 8, 597-608.

210. Franke, K. W.; Potter, V. R. A. J. Nutr. 1935, 10, 213-221.

211. Franke, K. W.; Painter, E. P. J. Nutr. 1935, 10, 599-611.

212. Painter, E. P.; Franke, K. W. J. Biol. Chem. 1935, 111, 643-651.

213. Franke, K. W. J. Nutr. 1934, 8, 609-612.

214. Li, H. F.; McGrath, S. P.; Zhao, F. J. New Phytol. 2008, 178, 92-102. http://dx.doi.org/10.1111/j.1469-8137.2007.02343.x

215. Dumont, E.; Vanhaecke, F.; Cornelis, R. Anal. Bioanal. Chem. 2006, 385, 1304-1323. http://dx.doi.org/10.1007/s00216-006-0529-8

216. Yang, G. Q.; Wang, S. Z.; Zhou, R. H.; Sun, S. Z. Am. J. Clin. Nutr. 1983, 37, 872-881.

217. Müller, D.; Desel, H. Hum. Exp. Toxicol. 2010, 29, 431-434. http://dx.doi.org/10.1177/0960327109360046

218. MacFarquhar, J. K.; Broussard, D. L.; Melstrom, P.; Hutchinson, R.; Wolkin, A.; Martin, C.; Burk, R. F.; Dunn, J. R.; Green, A. L.; Hammond, R.; Schaffner, W. Arch. Int. Med. 2010, 170, 256-261. http://dx.doi.org/10.1001/archinternmed.2009.495

219. Aldosary, B. M.; Sutter, M. E.; Schwartz, M.; Morgan, B. W. Clin. Toxicol. 2012, 50, 57-64. http://dx.doi.org/10.3109/15563650.2011.641560

220. Vinceti, M.; Wei, E. T.; Malagoli, C.; Bergomi, M.; Vivoli, G. 2001. Rev. Environ. Health 2001, 16, $233-252$. http://dx.doi.org/10.1515/REVEH.2001.16.4.233

221. Block, R. J.; Bolling, D. J. Biol. Chem. 1939, 127, 685-693.

222. Priya, M. D .L.; Geetha, A. Biol. Trace Elem. Res. 2011, 142, 148-158. http://dx.doi.org/10.1007/s12011-010-8766-2

223. Morris, J. S.; Stampfer, M. J.; Willett, W. Biol. Trace Elem. Res. 1983, 5, 529-537. http://dx.doi.org/10.1007/BF02988944

224. Puntel, R. L.; Roos, D. H.; Seeger, R. L.; Aschner, M.; Rocha, J. B. T. Neurotox. Res. 2013, 24, $109-118$. http://dx.doi.org/10.1007/s12640-012-9365-0

225. Santofimia-Castaño, P.; Salido, G. M.; González, A. DNA Cell Biol. 2013, 32, 147-155. http://dx.doi.org/10.1089/dna.2012.1939

226. Zadehvakili, B.; McNeill, S. M.; Fawcett, J. P.; Giles, G. I. Biochem. Pharmacol. 2016, 104, $19-28$. http://dx.doi.org/10.1016/j.bcp.2016.01.012

227. Puntel, R. L.; Ávila, D. S.; Roos, D. H.; Pinton, S. Curr. Org. Chem. 2016, 20, 198-210. http://dx.doi.org/10.2174/1385272819666150724234948

228. Plano, D. Baquedano, Y.; Ibánez, E.; Jiménez, I.; Palop, J. A.; Spallholz, J. E.; Sanmartín, C. Molecules 2010, 15, 7292-7312.

http://dx.doi.org/10.3390/molecules15107292

229. Gusberg, S. B.; Zamecnik, P.; Aub, J. C. J. Pharm. Exp. Ther. 1941, 71, 239-245.

230. El-Bayoumy, K.; Chae, Y. H.; Upadhyaya, P.; Meschter, C.; Cohen, L. A.; Reddy, B. S. Cancer Res. 1992, 52, 2402-2407.

231. El-Bayoumy, K.; Sinha, R. Mutat. Res. Fund. Mol. Mech. Mut. 2004, 551, 181-197. http://dx.doi.org/10.1016/i.mrfmmm.2004.02.023 
232. Ip, C.; El-bayoumy, K.; Upadhyaya, P.; Ganther, H.; Vadhanavikit, S.; Thompson, H. Carcinogenesis 1994, 15, 187-192.

http://dx.doi.org/10.1093/carcin/15.2.187

233. Nayini, J.; El-bayoumy, K.; Sugie, S.; Cohen, L. A.; Reddy, B. S. Carcinogenesis 1989, 10, 509-512. http://dx.doi.org/10.1093/carcin/10.3.509

234. Rosseti, I. B.; Wagner, C.; Fachinetto, R.; Taube Junior, P.; Costa, M. S. Mycoses 2011, 54, 506-513. http://dx.doi.org/10.1111/j.1439-0507.2010.01888.x

235. Loreto, É. S.; Nunes Mario, D. A.; Santurio, J. M.; Alves, S. H.; Nogueira, C. W.; Zeni, G. Mycoses 2011, 54, 572-576. http://dx.doi.org/10.1111/j.1439-0507.2010.01994.x

236. Rosseti, I. B.; Rocha, J. B. T.; Costa, M. S. J. Trace Elem. Med. Biol. 2015, 29, 289-295. http://dx.doi.org/10.1016/j.jtemb.2014.08.001

237. Dąbrowska, E.; Pįętka-Ottlik, M.; Palus, J. Phosphorus Sulfur Silicon. 2008, 183, 1082-1086. http://dx.doi.org/10.1080/10426500801901194

238. Rosseti, I. B.; Taube Junior, P.; de Campos, C. B. L., Rocha, J. B. T.; Costa, M. S. Curr. Drug Discov. Technol. 2014, 11, 234-238. http://dx.doi.org/10.2174/1570163811666140924121758

239. Venturini, T. P.; Chassot, F.; Loreto, É. S.; Keller, J. T.; Azevedo, M. I.; Zeni, G.; Santurio, J. M.; Alves, S. H. Med. Mycol. 2016, 54, 550-555.

http://dx.doi.org/10.1093/mmy/myv120

240. Saluk, J.; Bijak, M.; Nowak, P.; Wachowicz, B. Bioorg. Chem. 2013, 50, 26-33.

http://dx.doi.org/10.1016/j.bioorg.2013.07.003

241. Carroll, L.; Davie Rolo, A. P.; Teodoro, J. S.; Palmeira, C. M. Free Radic. Biol. Med. 2012, 52, 59-69. http://dx.doi.org/10.1016/j.freeradbiomed.2011.10.003

242. Rubio-Perez, J. M.; Morillas-Ruiz, J. M. Sci. World J. 2012, doi:10.1100/2012/756357 http://dx.doi.org/10.1100/2012/756357

243. Trinchieri, G. Ann. Rev. Immunol. 2012, 30, 677-706. http://dx.doi.org/10.1146/annurev-immunol-020711-075008

244. Alfadda, A. A.; Sallam, R. M. Reactive oxygen species in health and disease (2012) J. Biomed. Biotechnol. 2012, doi:10.1155/2012/936486.

http://dx.doi.org/10.1155/2012/936486

245. Maes, M.; Fišar, Z.; Medina, M.; Scapagnini, G.; Nowak, G.; Berk, M. Inflammopharmacology 2012, 20, 127-150.

http://dx.doi.org/10.1007/s10787-011-0111-7

246. Franceschi, C.; Campisi, J. J. Gerontol.A Biol. Sci. Med. Sci. 2014, 69, S4-S9. http://dx.doi.org/10.1093/gerona/glu057

247. Radi, R. J. Biol. Chem. 2013, 288, 26464-26472. http://dx.doi.org/10.1074/jbc.R113.472936

248. Zhu, H.; Li, Y. R. Exp. Biol. Med. 2012, 237, 474-480. http://dx.doi.org/10.1258/ebm.2011.011358

249. Hassan, W.; Noreen, H.; Castro-Gomes, V.; Mohammadzai, I.; Rocha, J. B. T.; Landeira-Fernandez, J. Curr. Pharm. Des. 2016, 22, 2960-2964.

http://dx.doi.org/10.2174/1381612822666160307145931 
250. Dias, V.; Junn, E.; Mouradian, M. M. J. Parkinsons Dis. 2013, 3, 461-491.

251. Pattison, D. I. Free Radic. Res. 2015, 49, 750-767. http://dx.doi.org/10.3109/10715762.2015.1018247

252. Schwarz, K.; Foltz, C. M. J. Biol. Chem. 1958, 233, 245-251.

253. Schwarz, K.; Foltz, C. M. J. Am. Chem. Soc. 1957, 79, 3292-3293.

http://dx.doi.org/10.1021/ja01569a087

254. Schwarz, K. A. Exp. Biol. Med. 1951, 78, 852-856.

http://dx.doi.org/10.3181/00379727-78-19240

255. DeWitt, W. B.; Schwarz, K. Experientia 1958, 14, 28-30. http://dx.doi.org/10.1007/BF02159659

256. Adams, W. Jr.; Kocsis, J. J.; Snyder, R. Toxicol. Lett. 1989, 48, 301-310. http://dx.doi.org/10.1016/0378-4274(89)90057-X

257. Schwarz, K.; Fredga, A. J. Biol. Chem. 1969, 244, 2103-2110.

258. Singh, N.; Sharpley, A. L.; Emir, U. E.; Masaki, C.; Herzallah, M. M.; Gluck, M.A.; Sharp, T.; Harmer, C. J.; Vasudevan, S. R.; Cowen, P. J.; Churchill, G. C. Neuropsychopharmacology 2016, 41, 1768-1778. http://dx.doi.org/10.1038/npp.2015.343

259. Masaki, C.; Sharpley, A. L.; Godlewska, B. R.; Berrington, A.; Hashimoto, T.; Singh, N.; Vasudevan, S. R.; Emir, U. E.; Churchill, G. C.; Cowen, P. J. Psychopharmacology 2016, 233, 1097-1104. http://dx.doi.org/10.1007/s00213-015-4189-2

260. Masaki, C.; Sharpley, A. L.; Cooper, C. M.; Godlewska, B. R.; Singh, N.; Vasudevan, S. R.; Harmer, C. J.; Churchill, G. C.; Sharp, T.; Rogers, R. D.; Cowen, P. J. Psychopharmacology 2016, 233, 2655-2661. http://dx.doi.org/10.1007/s00213-016-4319-5

261. Churchill, G. C.; Singh, N.; Vasudevan, S. Biochemist 2013, 35, 16-19.

262. Thangamani, S.; Younis, W.; Seleem, M. N. Sci. Rep. 2015, 5, 11596. http://dx.doi.org/10.1038/srep11596

263. Gustafsson, T. N.; Osman, H.; Werngren, J.; Hoffner, S.; Engman, L.; Holmgren, A. Biochem. Biophys. Acta 2016, 1860, 1265-1271.

http://dx.doi.org/10.1016/j.bbagen.2016.03.013

264. Thenin-Houssier, S.; De Vera, I. M. S.; Pedro-Rosa, L.; Brady, A.; Richard, A.; Konnick, B.; Opp, S.; Buffone, C.; Fuhrmann, J.; Kota, S.; Billack, B.; Pietka-Ottlik, M.; Tellinghuisen, T., Choe, H., Spicer, T., Scampavia, L., Diaz-Griffero, F., Kojetin, D. J., Valentea, S. T. Antimicrob. Agents Chemother. 2016, 60, 2195-2208. http://dx.doi.org/10.1128/AAC.02574-15

265. Lu, J.; Vlamis-Gardikas, A.; Kandasamy, K.; Zhao, R.; Gustafsson, T. N.; Engstrand, L., Hoffner; S., Engman, L.; Holmgren, A. FASEB J. 2013, 27, 1394-1403. http://dx.doi.org/10.1096/fj.12-223305

266. Bender, K. O.; Garland, M.; Ferreyra, J. A.; Hryckowian, A. J.; Child, M. A.; Puri, A. W.; Solow-Cordero, D. E.; Higginbottom, S. K.; Segal, E.; Banaei, N.; Shen, A. Sci. Transl. Med. 2015, doi: 10.1126/scitransImed.aac9103 http://dx.doi.org/10.1126/scitranslmed.aac9103

267. Baek, J. M.; Kim, J. Y.; Yoon, K. H.; Oh, J.; Lee, M. S. Int. J. Biol. Sci. 2016, 12, 478-488. http://dx.doi.org/10.7150/ijbs.13815

268. Wirth, T. Angew. Chem. Int. Ed. 2015, 54, 10074-10076. http://dx.doi.org/10.1002/anie.201505056 
269. Elsherbini, M.; Hamama, W. S.; Zoorob, H. H.; Bhowmick, D.; Mugesh, G.; Wirth, T. Heteroatom Chem. 2014, 25, 320-325.

http://dx.doi.org/10.1002/hc.21164

270. Selvakumar, K.; Shah, P.; Singh, H. B.; Butcher, R. J. Chem. Eur. J. 2011, 17, 12741-12755. http://dx.doi.org/10.1002/chem.201100930

271. Satheeshkumar, K.; Mugesh, G. Chem. Eur. J. 2011, 17, 4849-4857. http://dx.doi.org/10.1002/chem.201003417

272. Pino, M. A.; Pietka-Ottlik, M.; Billack, B. Cutan. Ocul. Toxicol. 2014, 33, 32-41. http://dx.doi.org/10.3109/15569527.2013.794818

273. Luo, Z.; Liang, L.; Sheng, J.; Pang, Y.; Li, J.; Huang, L.; Li, X. Bioorg. Med. Chem., 2014, 22, 1355-1361. http://dx.doi.org/10.1016/i.bmc.2013.12.066

274. Mao, F.; Chen, J.; Zhou, Q.; Luo, Z.; Huang, L.; Li, X. Bioorg. Med. Chem. Lett. 2013, 23, 6737-6742. http://dx.doi.org/10.1016/i.bmcl.2013.10.034

275. Wang, Z.; Li, W.; Wang, Y.; Li, X.; Huang, L.; Li, X. RSC Adv. 2016, 6, 7139-7158. http://dx.doi.org/10.1039/C5RA26797H

276. Olson, O. E. J. Am. Coll. Toxicol. 1986, 5, 45-70. http://dx.doi.org/10.3109/10915818609140736

277. Pinsent, J. Biochem. J. 1954, 57, 10-16.

278. Chambers, I.; Frampton, J.; Goldfarb, P.; Affara, N.; McBain, W.; Harrison, P. R. EMBO J. 1986, 5, 12211227.

279. Zinoni, F.; Birkmann, A.; Stadtman, T. C.; Bock, A. Proc. Natl. Acad. Sci. U. S. A. 1986, 83, 4650-4654. http://dx.doi.org/10.1073/pnas.83.13.4650

280. Lee, B. J.; Worland, P. J.; Davis, J. N.; Stadtman, T. C.; Halfield, D. J. J. Biol. Chem. 1989, 264, 9724-9727. 281. Heider, J.; Baron, C.; Böck, A. EMBO J. 1992, 11, 3759-3766.

\section{Authors' Biographies}

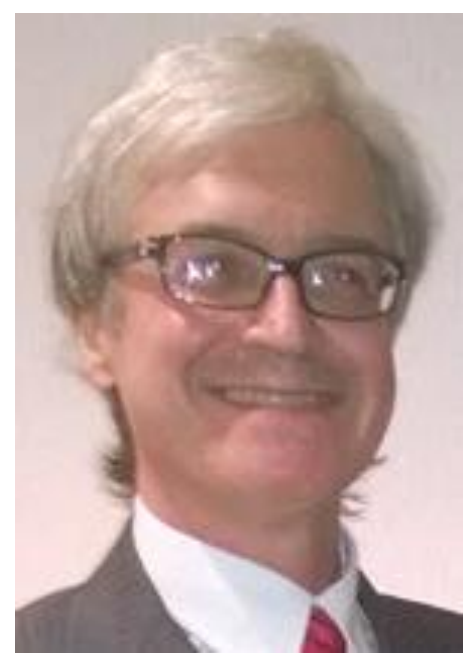

João B. T. Rocha was born in Rio de Janeiro, Brazil, in 1964. He received his degree in Biological Sciences at the Universidade Federal do Rio Grande do Sul, Porto Alegre, Brazil, in 1987. Dr. Rocha received his PhD degree working under the direction of Prof. Diogo Onofre Souza in 1996. In 1989, he joined the Biochemistry 
Department at Universidade Federal de Santa Maria, RS, Brazil, where he is presently University Professor of Biochemistry. In 1997, he received a CNPq Postdoctoral Fellowship to work with Prof. L. De Meis at the Federal University of Rio de Janeiro. His current research interests include the development of new in vitro and in vivo methods to test the toxicity and potential therapeutic use of simple organoselenium compounds. The toxicity studies are centered on the reactivity of thiol-containing low mass molecular compounds and proteins, such as ALA-D and LDH with organoselenium compounds. The interaction of selenol intermediates with methylmercury is also under investigation in his laboratory.

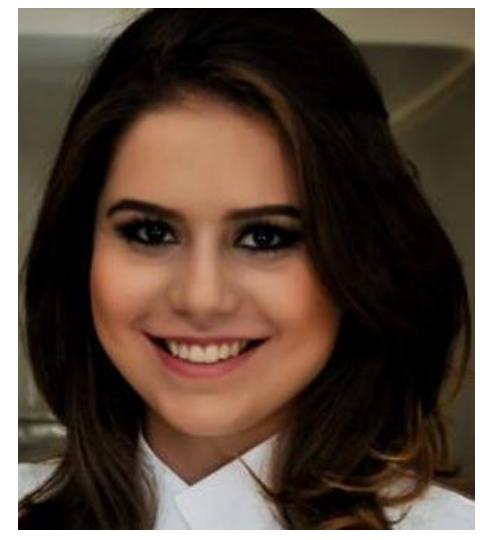

Bruna C. Piccoli was born in Uruguaiana, Brazil, in 1992. She is a graduate in Nutrition at Centro Universitário Franciscano. She is doing a Master's degree in Universidade Federal de Santa Maria under the supervision of Prof. João Batista Teixeira da Rocha. Her Master's degree thesis concerns the environmental toxicants methylmercury and 4-vinylcyclohexene and their relationship with oxidative stress and protection by organoselenium compounds.

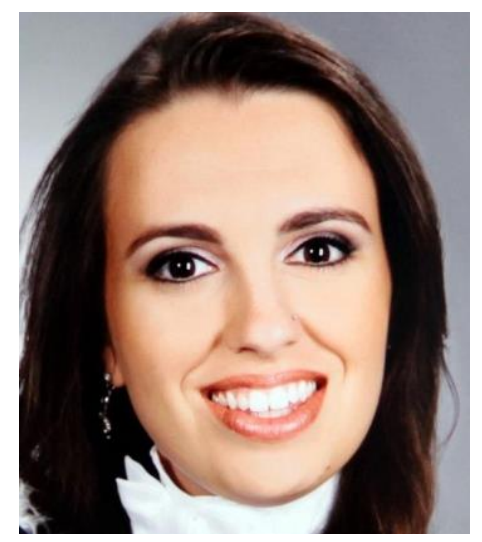

Cláudia S. Oliveira was born in Venâncio Aires, Brazil, in 1987. She is was an undergraduate in Biological Science at Universidade Federal de Santa Maria and completed her PhD degree in Toxicological Biochemistry under the direction of Prof. Maria Ester Pereira in 2015 at the same University. Now she has a postdoctoral position with Prof. João Batista Teixeira da Rocha. Her scientific interest has been concentrated on the toxic effects of inorganic and organic mercury in the early stages of development. Recently, she started to work on the benefits of organoselenium compounds against the toxic effects of mercury. 